\title{
Поясные наборы в культуре кочевников Тувы
}

\section{Марина Е. Килуновская, Владимир А. Семенов, Анатолий В. Семенов, Варвара С. Бусова}

Институт истории материальной культуры РАН, Российская Федерация

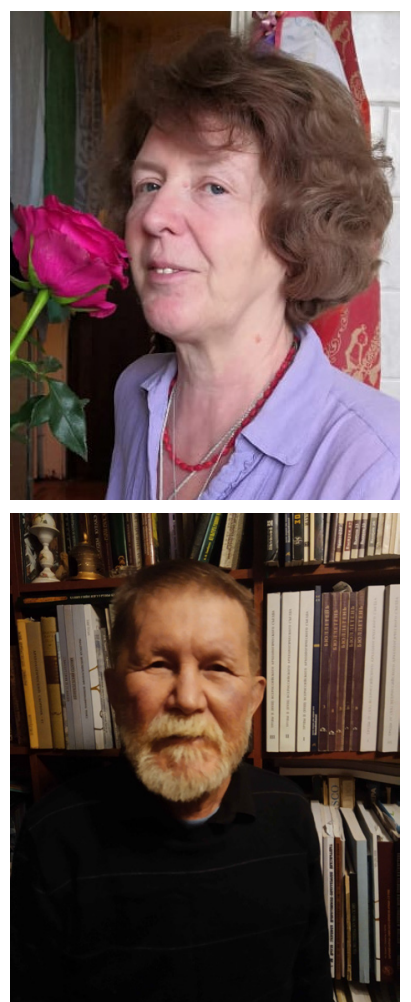

Одним из важнейших компонентов культуры номадов Центральной Азии является пояс, который обладает важной прагматической функцией, но также имеет символическое значение. Благодаря этим свойствам в поясной фурнитуре и конструкции пояса четко отражаются те культурно-исторические процессы, которые происходят в обществе кочевников, он является своего рода очень ярким хронологическим индикатором. Начиная со раннескифского времени (с VIII до н. э.) и вплоть до позднего средневековья широкое распространение получили т. н. наборные пояса, в которых на кожаную основу надевались различные металлические и костяные украшения и к ней подвешивались необходимые предметы и оружие. В тувинской культуре кожаные ремни в основном используются как охотничьи - портупейные, для ношения оружия. Кроме того, с этого же времени используются тканые пояса, которыми и по сей день тувинцы подпоясывают халаты. В оформлении этого важного атрибута можно проследить некоторую культурную преемственность между кочевниками скифской эпохи и «этнографическими», обусловленную, среди прочего, единством хозяйственно-культурного типа.

Ключевые слова: кочевники; скифское время; Тува; тувинцы; традиционная одежда; пояс; поясная фурнитура

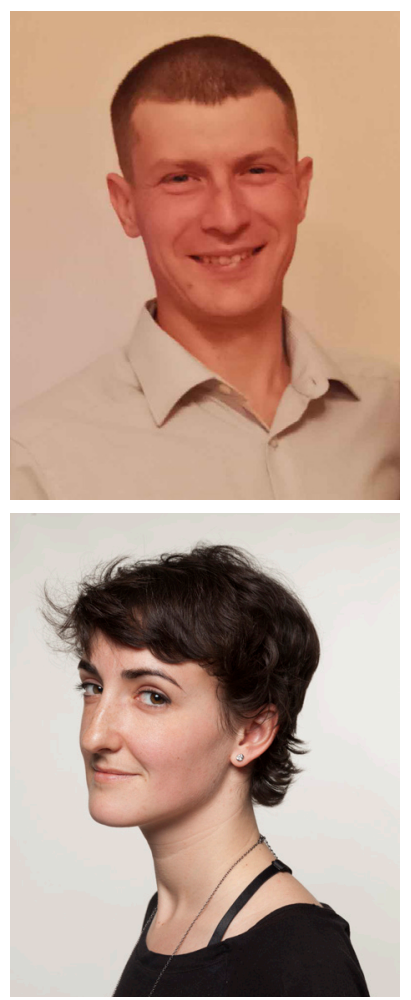

Финансирование

Исследование проведено в рамках выполнения программы фундаментальных научных исследований государственных академий наук по теме государственной работы: «Динамика взаимодействия древних культур Северной Евразии и цивилизаций Востока в эпоху палеометалла (IV тысячелетие до н. э. - I тысячелетие до н. э.)».

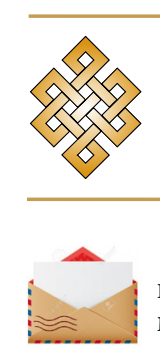

Для цитирования:

Килуновская М. Е., Семенов Вл. А., Семенов А. В., Бусова В. С. Поясные наборы в культуре кочевников Тувы // Новые исследования Тувы. 2021. № 1. С. 30-50. DOI: https://www.doi.org/10.25178/nit.2021.1.2

Килуновская Марина Евгеньевна - кандидат исторических наук., старший научный сотрудник Отдела археологии Центральной Азии и Кавказа Института истории материальной культуры РАН. Адрес: 191186, Россия, г. Санкт-Петербург, Дворцовая наб., д. 18. Тел.: +7 (911) 191-52-06. Эл. адрес: kilunmar@mail.ru

Семенов Владимир Анатольевич - кандидат исторических наук., старший научный сотрудник Отдела археологии Центральной Азии и Кавказа Института истории материальной культуры РАН. Адрес: 191186, Россия, г. Санкт-Петербург, Дворцовая наб., д. 18. Тел.: +7 (911) 266-04-53. Эл. адрес: ranbov@yandex.ru

Семенов Анатолий Владимирович - младший научный сотрудник Лаборатории камеральной и цифровой обработки, учета и хранения археологических коллекций Института истории материальной культуры РАН. Адрес: 191186, Россия, г. Санкт-Петербург, Дворцовая наб., д. 18. Тел.: +7 (911) 139-31-34. Эл. адрес: blaze85@inbox.ru

Бусова Варвара Сергеевна - младший научный сотрудник Отдела археологии Центральной Азии и Кавказа Института истории материальной культуры РАН. Адрес: 191186, Россия, г. СанктПетербург, Дворцовая наб., д. 18. Тел.: +7 (921) 300-92-98. Эл. адрес: kulturnijkarman@gmail.com 


\title{
Decorated belts in the culture of the nomads of Tuva
}

\author{
Marina E. Kilunovskaya, Vladimir A. Semenov, Anatoly V. Semenov, Varvara S. Busova \\ Institute for the History of Material Culture, Russian Academy of Sciences, Russian Federation
}

\begin{abstract}
One of the most important components of the nomadic cultures of Central Asia is the belt, which is both of huge pragmatic importance and endowed with a symbolic meaning. This makes it possible to match the structural features of the belt and its accessories and the cultural and historical developments in a nomadic society, with the former being excellent indicators of the latter.

From the early Scythian times (8th century BC and later) and up to the late Middle Ages, the so-called 'decorated belts' reached the peak of their popularity. The leather belt of this type was covered with metallic or bone decorations which were used for attaching the staple items and weapons. In Tuvan culture, leather belt is mainly worn as a shoulder rig to carry weapon. At the same time, textile belts were also used (and have survived up to now) as a robe girdle. The use of this important accessory reveals a certain cultural continuity between Scythian-time nomads and the 'ethnographic' nomadism, due to, among other things, the similarity between their economies and cultures.
\end{abstract}

Keywords: nomads; Scythian period; Tuva; Tuvans; traditional costume; belt; belt fittings

\section{Financing}

The article was written as part of the study in accordance with the program of fundamental studies for state academies of sciences, "The dynamics of interaction between ancient cultures of Northern Eurasia and civilizations of the East in the paleometallic age (4th1st millennium $B C$ )".

\section{For citation:}

Kilunovskaya M. E., Semenov V. A. Semenov A. V. and Busova V. S. Decorated belts in the culture of the nomads of Tuva. New Research of Tuva, 2021, no. 1, pp. 30-50. (In Russ.). DOI: https://www.doi.org/10.25178/nit.2021.1.2

KILUNOVSKAYA, Marina Evgenievna, Candidate of History, Senior Researcher, Department of Archaeology of Central Asia and the Caucasus, Institute for the History of Material Culture, Russian Academy of Sciences. Postal address: 18 Dvortsovaya nab., 191186 Saint-Petersburg, Russia. Tel.: +7 (911) 191-52-06. E-mail: kilunmar@mail.ru

ORCID ID: 0000-0001-6458-9166

SEMENOV, Vladimir Anatolievich, Candidate of History, Senior Researcher, Department of Archaeology of Central Asia and the Caucasus, Institute for the History of Material Culture, Russian Academy of Sciences. Postal address: 18 Dvortsovaya nab., SaintPetersburg 191186, Russia. Tel.: +7 (911) 266-04-53. E-mail: ranbov@yandex.ru

ORCID ID: 0000-0002-1487-9277

SEMENOV, Anatoly Vladimirovich, Junior Researcher, Laboratory of treatment and digital processing of archaeological collections, Institute for the History of Material Culture, Russian Academy of Sciences. Postal address: 18 Dvortsovaya nab., Saint-Petersburg 191186, Russia. Tel.: +7 (911) 139-31-34.E-mail: blaze85@inbox.ru

ORCID ID: 0000-0002-6655-1783

BUSOVA, Varvara Sergeevna, Junior Researcher, Department of Archaeology of Central Asia and the Caucasus, Institute for the History of Material Culture, Russian Academy of Sciences. Postal address: 18 Dvortsovaya nab., Saint-Petersburg 191186, Russia. Tel.: +7 (921) 300-92-98. E-mail: kulturnijkarman@gmail.com 


\section{Введение}

C начала I тыс. до н. э. до XX в. мы можем документально проследить развитие традиционного пояса, который является неотъемлемой частью одежды у кочевых народов. Происходят изменения как в технологии изготовлении его основы - кожаной или текстильной, так и в системах крепления пряжках, украшения - бляхах, обоймах, подвесках. В поясной фурнитуре и конструкции пояса весьма наглядно отражаются те культурно-исторические процессы, которые происходят в обществе кочевников: он является ярким социальным показателем и хронологическим индикатором, сохраняя определённые символические свойства.

Проблемам, связанным с поясами кочевников степного пояса Азии и прилегающих к нему природных зон, посвящена обширная литература, в которой рассматриваются как технологические аспекты, продиктованные технологией изготовления, реконструкцией крепления, развитием различных элементов, а также с символическим значением (Добжанский, 1990; Черемисин, 2008; Шульга, 2008; Кубарев, Шульга, 2007; Чугунов, 2016 и др.). Особенно нужно отметить фундаментальный труд С. А. Яценко, в котором дана характеристика поясной одежде и поясу в рамках реконструкции облика основных элементов костюма каждого этноса в ахменидо-скифское время (Яценко, 2006).

Целью данной работы является разноплановое изучение такого важнейшего костюмного аксессуaра, как пояс, применительно к кочевникам Тувы скифской эпохи и «этнографического» времени, выявление возможной преемственности между поясами этих далеких друг от друга эпох. Научная новизна работы в том, что она является первым достаточно полным комплексным исследованием поясов разных культур Тувы скифского времени на более широком территориальном и хронологическом фоне. Эта тема в последнее время привлекает внимание многих ведущих исследователей, мнение которых мы постарались учесть в нашей работе, но полученные новые данные помогают нам по-новому взглянуть на некоторые аспекты, связанные с культурно-хронологической интерпретацией данного аспекта материальной культуры номадов Центральной Азии и сопредельных территорий. Источниковая база включает, прежде всего, практически всю совокупность поясов «скифских» культур региона, включая новые находки, полученные в ходе исследований Тувинской археологической экспедиции Института истории материальной культуры Российской академии наук.

\section{Пояс как важнейшая часть одежды в традиционной культуре тувинцев}

Пояс являлся неотъемлемой частью традиционной одежды тувинцев. Это вполне объяснимо, так как у верхней одежды (халатов, шуб, кафтанов, штанов, юбок, рубах) со скифского времени отсутствовали карманы, и различные необходимые вещи подвешивались к поясу. Самым распространённым в тувинской культуре являлся пояс, сделанный из материи кур (фото 1). Его образовывало полотнище шириной

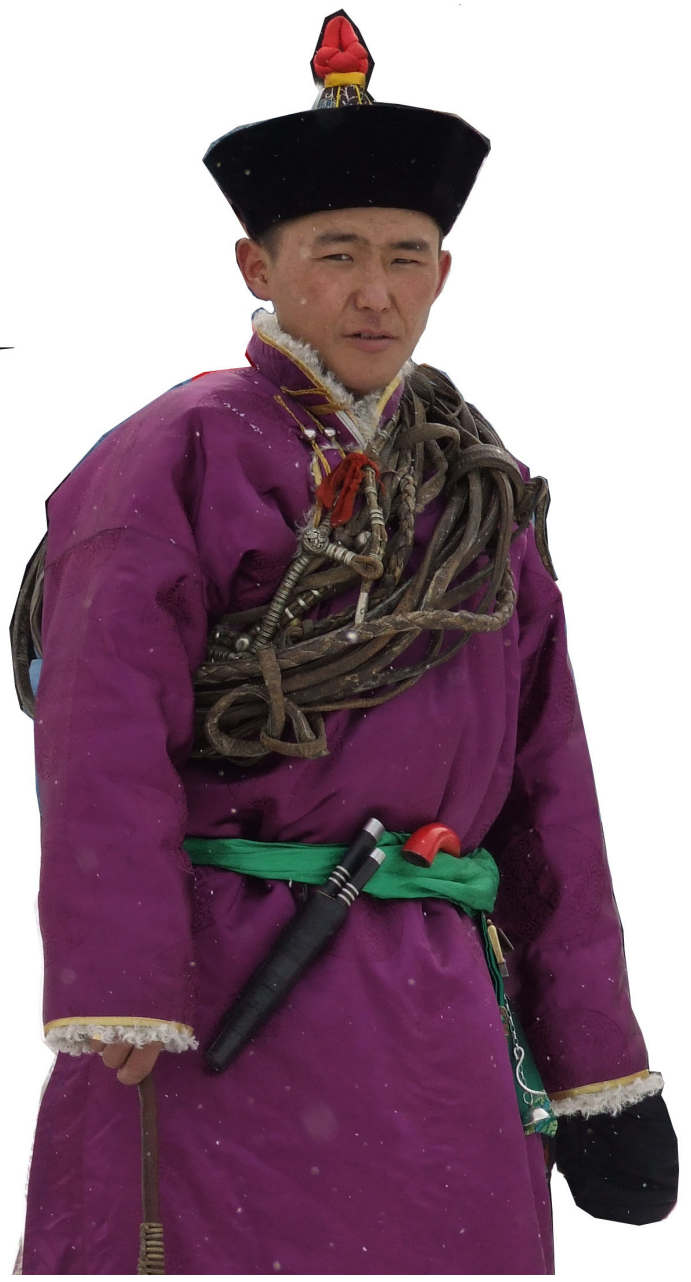

Фото 1. Тувинец в национальном костюме. Фото А. И. Евсеева, 2015 г.

Photo 1. A Tuvan wearing ethnic clothes. Photo by A. I. Evseev, 2015. до 50 см и длиной от 3 до 6 м, которое наматывалось в несколько раз вокруг талии (Вайнштейн, 1991: 178; Тува в беге ..., 2014: 40-41). Богатые пояса делались из шелка. Женские и мужские пояса (как и многих других народов мира) отличались по цвету: первые были яркими красными, оранжевыми, голубыми, а вторые коричневыми или синими (Потапов, 1969: 215). 

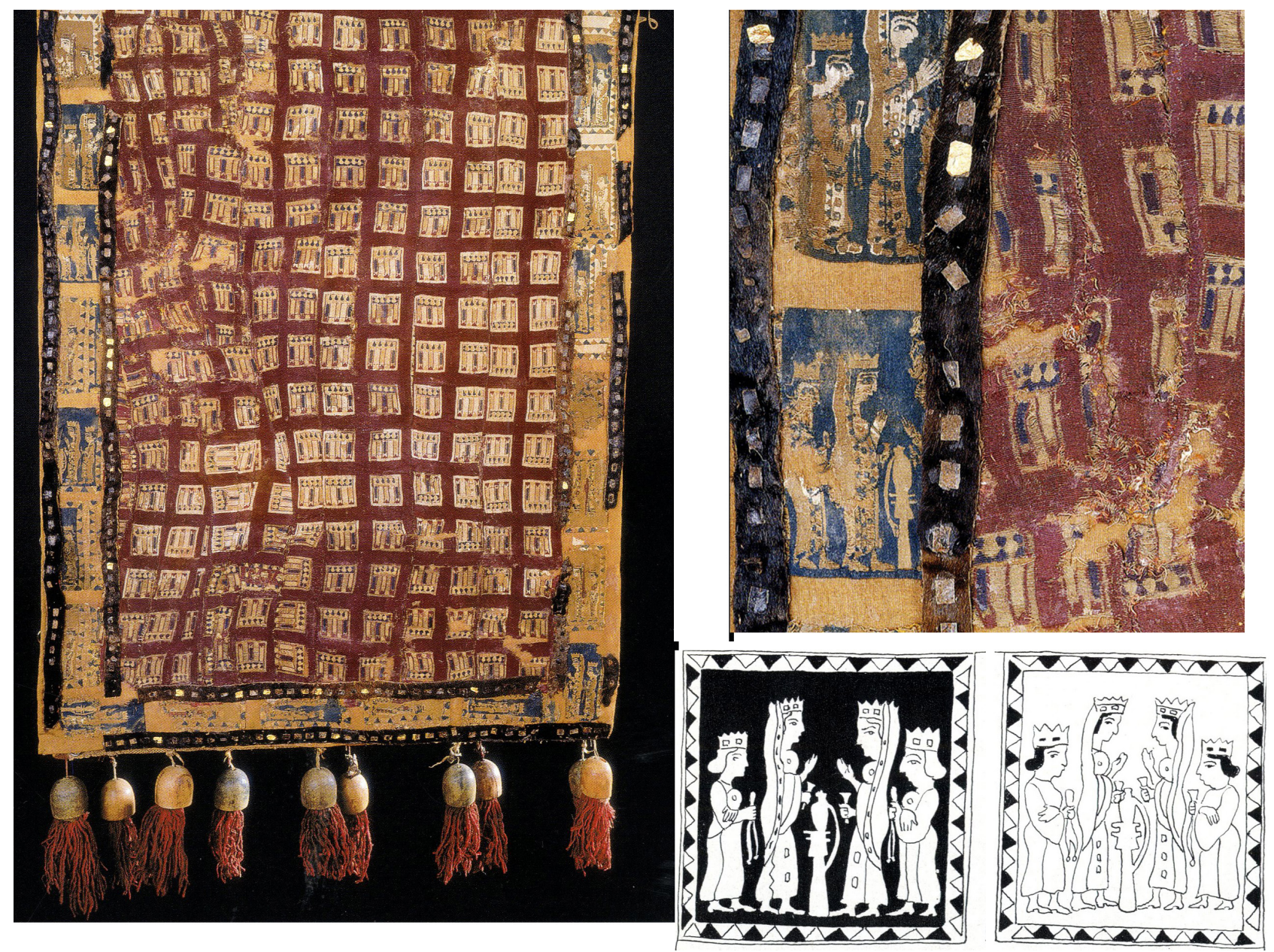

Рис 1. Фрагмент ближневосточной ткани из Пятого Пазырыкского кургана (Горный Алтай): 1 - чепрак;

2 - изображение женских фигур с кусти; 3, 4- сцены с изображением женщин и богини (по: Семенов, 2019).

Fig. 1. A fragment of Middle Eastern cloth from Pazyryk V kurgan (Gorny Altai): 1 - cheprak, 2 - female figure wearing a kusti, 3 and 4 - scenes with women and the goddess (from Semenov, 2019).

Традиция таких поясов достаточно древняя, как указывал С. И. Вайнштейн, существовавшая по крайней мере с XIII в. (Вайнштейн, 1991: 178). Однако ее истоки можно проследить и раньше. Так на фрагментах ткани ближневосточного происхождения из Пятого Пазырыкского кургана на соседнем с Тувой Алтае, покрывавших войлочный чепрак под седло лошади, представлена сцена с двумя парами женщин в молитвенных позах, поклоняющихся божеству ${ }^{1}$. В руках у них находятся полоски ткани с кистями на концах, которые аналогичны священному поясу зороастрийцев («кусти» / «кустич» на пехлеви) (рис. 1). Этот пояс плели из 72 (по количеству глав Ясны) шерстяных нитей. Носят кусти все зороастрийские мужчины и женщины, трижды обернув им поясницу и завязав узлом спереди и сзади. В пятнадцатилетнем возрасте в зороастризме совершается обряд посвящения, после чего верующий обязан сам развязывать и вновь завязывать этот пояс каждый день всю последующую жизнь во время молитвы. Ему посвящены некоторые разделы Авесты, и он является показателем ритуальной чистоты (Семенов, 2019: 3-13). Пояса из тканей разных цветов и ширины зафиксированы у ираноязычных народов с ахеменидско-скифского времени (Яценко, 2006: 28-110).

То, что пояс в тувинской культуре служил не только прагматическим целям, но и выполнял функции оберега и имел апотропеические (защитные) свойства, говорит и то, что к нему подвешивались разные амулеты, а у детей медные бубенчики (Потапов, 1969: 216). Но пояс у детей появлялся не сразу, по некоторым данным - только по достижении 6 лет. В. П. Дьяконова столкнулась в своей полевой работе

${ }^{1}$ Фрагменты ближневосточных тканей сегодня датируются V-IV вв. до н. э., а сами погребальные комплексы IV-III вв. до н. э. 
с утверждением нарынских тувинцев ${ }^{1}$, что человек, простой ли он житель или лама, имеет три души: 1) муу-сунус - плохая душа, 2) дунд-сунус - средняя душа и 3) сайн-сунус - хорошая душа. Сайн-сунус предохраняет человека от всяких бед и охраняет его. Как только у ребёнка появляется пояс, сайн-сунус «поселяется» в нем и неотлучно обитает в нем до смерти человека. Поэтому пояс нельзя никому ни дарить, ни продавать (Дьяконова, 1975: 88).

Как указывает В. К. Даржа, широкий тканый пояс удобен для езды на коне (он держит осанку), а также одевался во время праздничных мероприятий. Но во время ходьбы, промысла или хозяйственных работ он неудобен, поэтому талия опоясывалась ремнями или верёвками (Даржа, 2009: 161-162). В материале нетканых поясов также наблюдается чёткое отличие мужского/женского - мужские делались из волоса, а женские из козьей шерсти (Потапов, 1969: 215). Они могли завязываться или же застёгиваться на медную или железную пряжку. Интересно, что на позднем этапе уюкскосаглынской культуры ${ }^{2}$ (IV-II вв. до н. э.) в женских погребениях зафиксирован особый вид поясов - на тонких ремнях или веревочках нанизаны небольшие цилиндрические аргилитовые пронизки и раковины каури, спереди они завязывались на бронзовую пятикольчатую пряжку и ворворку; по бокам от пояса также на тонких ремешках крепились различные амулеты из клыков животных, вырезанные из кости в виде костыльков, колоколовидных и антропоморфных подвесок, миниатюрные бронзовые модели котелков и др. (рис. 2). По-видимому, мы имеем здесь дело с сохранением некоторых традиций, связанных в первую очередь с апотропеическими функциями поясов. Все эти предметы могут рассматриваться как обереги. Такие пояса, представляющие собой низку амулетов, которым придавалась охранная сила, широко распространены как в Европейской Скифии и на Кав-
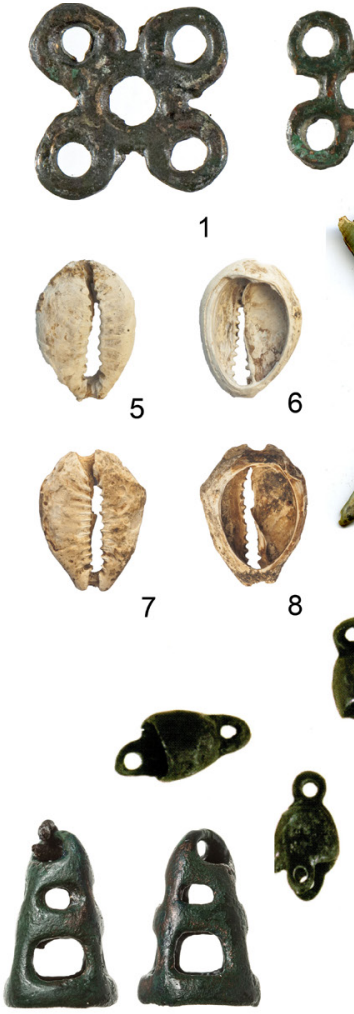

12
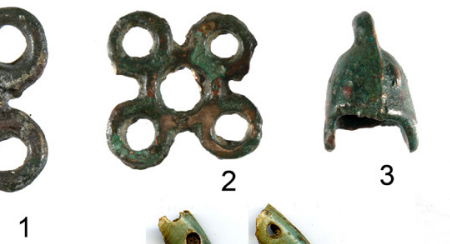

3
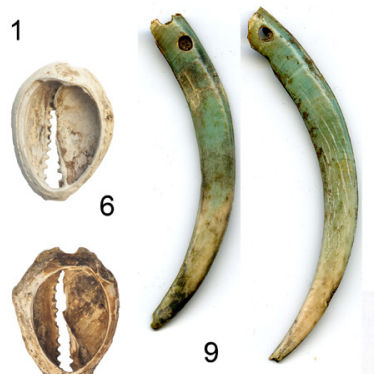

10
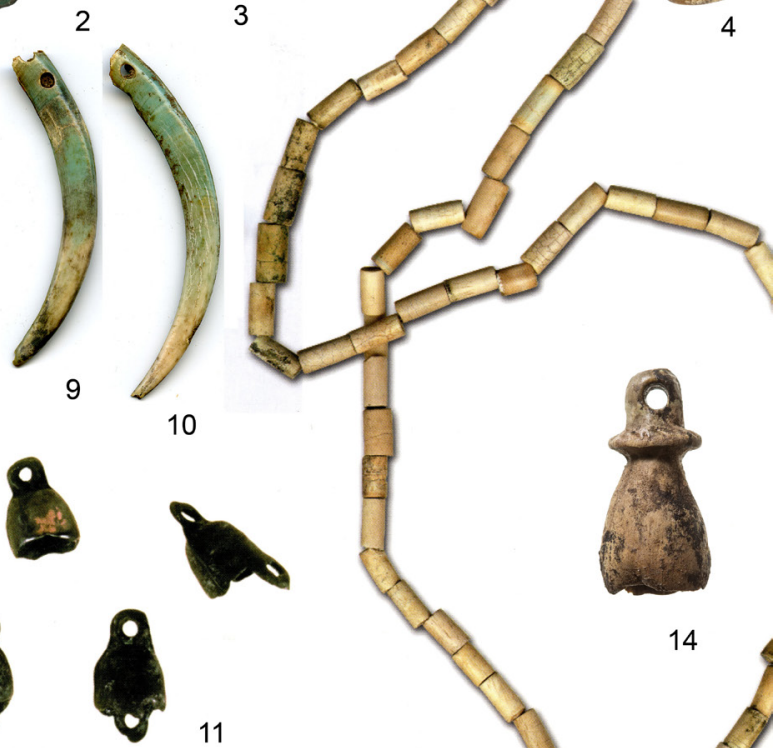

13

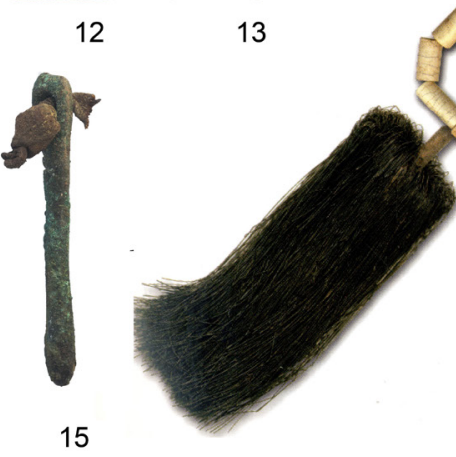

Рис. 2. Женский пояс и поясные украшения из курганов озен-ала-белигского этапа уюкско-саглынской культуры: 1-3, 11-15, 17 - бронза, 4-клык марала, 5-8 - раковины каури, 9, 10 - клыки кабарги; 14-костяная подвеска;

16 - аргилитовые пронизки, нанизанные на кожаный ремешок. Фото Вл. А. Семенова и М. Е. Килуновской, 2016 г.

Fig. 2. Female belt and belt accessories from the kurgans of Ozen-Ala-Belig stage of Oyuk-Saglyn culture: 1-3, 11-15, 17 - bronze, 4-Siberian stag tooth, 5-8-cowrie shells, 9-10 - Siberian musk deer teeth, 14-a bone pendant; 16 - argillite pieces on a leather strap. Photos by VI. A. Semenov and M. E. Kilunovskaya, 2016.

${ }^{1}$ Нарынские тувинцы - жители с. Нарын Эрзинского района, приграничного с Монголией, и родным для них является монгольский язык. Поэтому В. П. Дьяконова приводит термины монгольского языка, правда без этого уточнения.

2 Уюкско-саглынская культура - культура скифского круга, распространенная в Туве в VI-II вв. до н. э. Для нее характерны коллективные захоронения в глубоких ямах в срубах. 


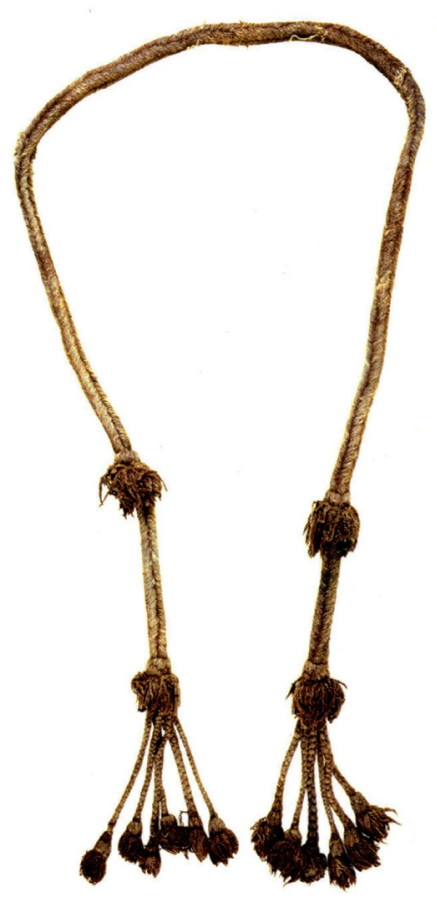

Рис. 3. Женский плетёный пояс из кургана 1 могильника Ак-Алаха 3 (по: Полосьмак, Баркова, 2005: 68, рис. 2, элемент 40). Fig. 3. A plaited female belt from kurgan 1 of the Ak Alakha 3 burial ground (from Polos'mak, Barkova, 2005: 68, Fig. 2, element 40).

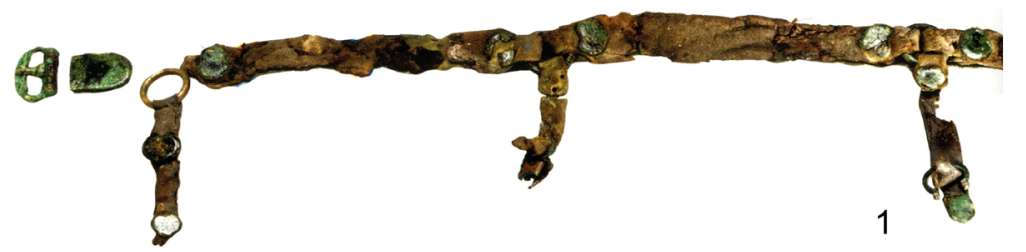

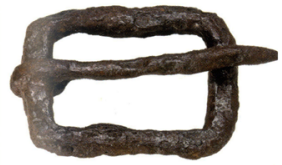

2

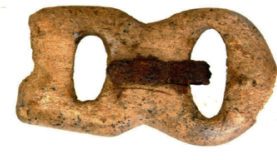

3

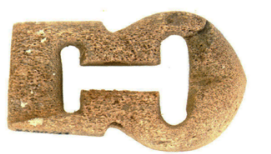

4
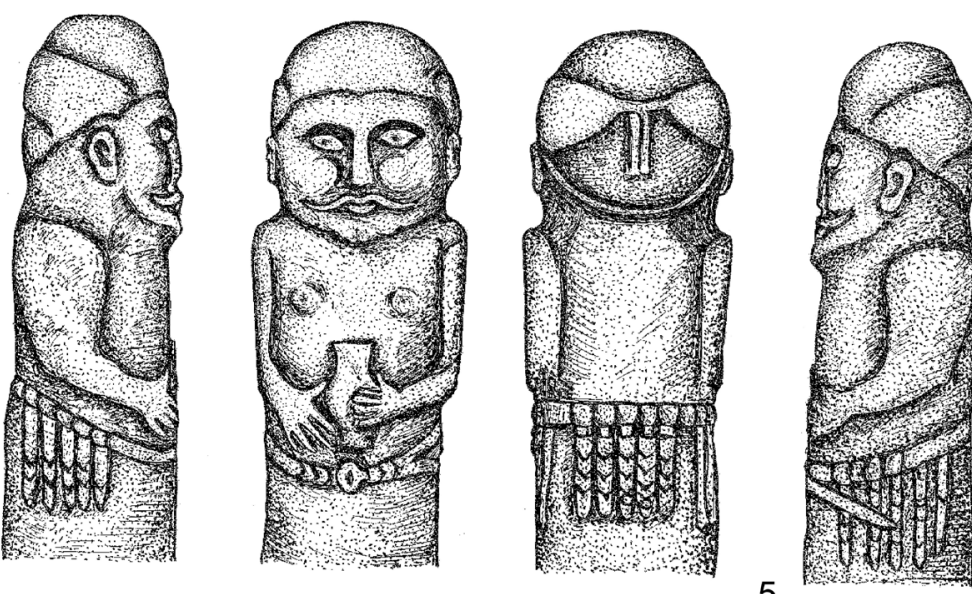

5

Рис 4. 1-4 - пояс и пряжки древнетюркского времени из раскопок А. Д. Грача 1957-1958 г2. в Монгун-Тайге и Саглы (Кочевники Евразии ..., 2012: 190-191); 5 - каменное изваяние из ур. Эльте-Кежиг (рисунок М. Е. Килуновской, 1989 г.)

Fig. 4. 1-4 - Old Turkic belt and buckles, excavated by A. D. Grach in 1957-1958 in Mongun-Taiga and Sagly (Kochevniki Evrazii... 2012: 190-191);

5 - a stone effigy from Elte-Kezhig (a drawing by M. E. Kilunovskaya, 1989).

казе, так и на Алтае и Туве (Яценко, 2006: 348). Особое значение придавалось раковинам каури, которые в большом количестве встречаются в курганах скифского и постскифского времени, в том числе - на поясах мужчин (Сулуг-Хем) (Escitas. Tesoros ..., 2008: 97). Кроме того, что они являлись ценным обменным эталоном (своего рода были монетами), они были символом достатка, женской фертильности (как зримый символ женской vulva), деторождения. Они сохранились на поясах шаманов Саяно-Алтая (Прокофьева, 1971: 90).

На сегодня реконструированы женские верёвочные пояса скифского времени, опираясь на находки из курганов с вечной мерзлотой на Алтае, так толстые плетеные шнурки с множеством завязок найдены в курганах Ак-Алаха и в Третьем Пазырыкском кургане (Полосьмак, Баркова, 2005: 68) (рис. 3). Остатки таких шнурков происходят из могильников Саускен и Аймырлыг в Туве. Можно утверждать, что женская юбка подпоясывалась с помощью текстильного пояса, выполненного из шерсти в технике дерганья.

Все исследователи указывают на то, что до начала XX века тувинцы, а особенно богатые сойоты, вместо кушака подпоясывались ремнём, украшенным серебряными и медными бляхами (Потапов, 1969: 215; Вайнштейн, 1991: 178). Безусловно, истоки этого находятся в древнетюркской культуре, где подобные пояса с прикреплёнными к ним с помощью заклёпок бляхами и пряжками, украшенными великолепным растительным орнаментом, находятся в погребениях (яркий образец такого пояса VIII-IX вв. представлен, например, в кургане 24 у с. Успенское, см.: Мир кочевников, 2013: 100, № 325) и изображены на каменных изваяниях - көжээ (рис. 4).

Но не только парадные, но и простые кожаные ремни имели широкое распространение с начала скифской эпохи (а может быть и ранее) ввиду своей прочности и возможности подвешивания к ним довольно тяжёлых предметов (колчана с луком, кинжалов, оселков и т. д.). Это боевые или охотничьи 
пояса, которые играли роль портупеи. Как известно, наиболее комфортный вес, который можно распределить на поясе для взрослого мужчины - это 5-6 кг. Но и эти 5-6 кг надо рационально распределить. Более того, для устойчивого положения в седле центр тяжести должен приходиться на низ живота, и всего 1,5-2 кг имеет смысл крепить к ногам. Все предметы вроде ворворок, застёжек и обойм крепятся на поясе на кожаных шнурках, которые либо держатся за счёт продевания ремня в ремень, либо - завязывания простым узлом, основным гарантом крепости которых является постоянное нахождение под весом или нагрузкой.

Таким образом в тувинской культуре можно проследить сохранение особенного отношения к поясу, которое фиксируется в скифское время и у тюрков. Оно отразилось в первую очередь в цветовой символике и способе ношения традиционного пояса кур, в тонких женских поясах, которые плелись из шерсти, использовании боевого кожаного пояса у мужчин, к которому подвешивались различные предметы.

\section{Развитие наборных поясов и поясной фурнитуры в скифское время}

Начиная с раннескифского времени (с VIII до н. э.) вплоть до позднего средневековья широкое распространение получили наборные пояса, в которых на кожаную основу надевались различные
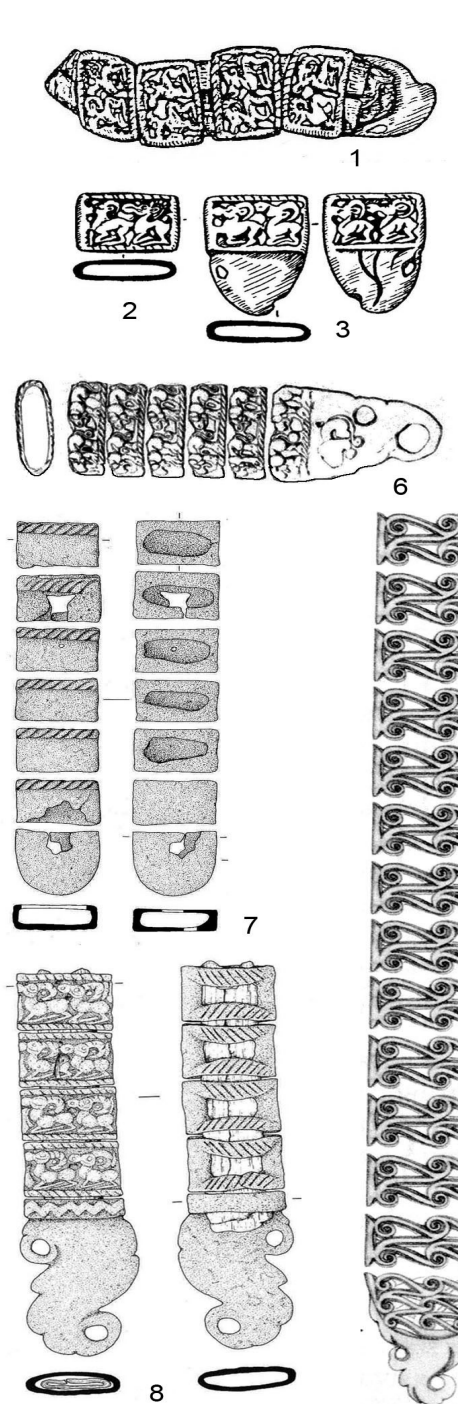

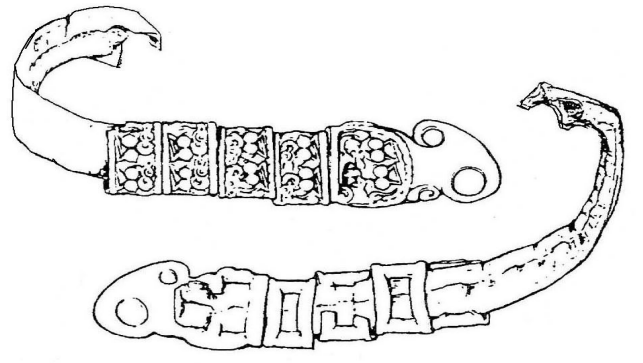

4

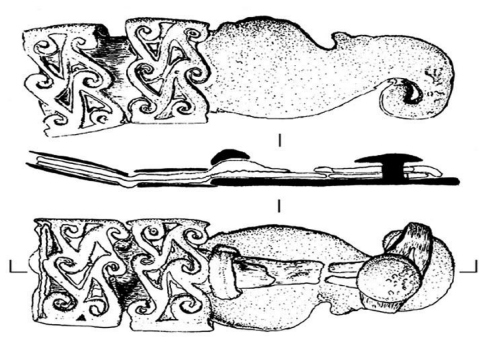

5

Рис. 5. Пояса из алды-бельских комплексов: 1-3 - Сыпучий Яр; 4 - Усть-Хадынныг I; 5 - Демир-Суг II (по: Монгуш К., Монгуши М., 2019: 20, рис. 2, 2);

6-9 - Аржан-2 и 10-12 - Чинге-Тей I (по: Чугунов, 2016: 337, 343, 345, 348, рис. 165, 168, 169, 174). Fig. 5. Belts from Aldy-Bel finds: 1-3 - from Sypuchy Yar, 4-from Ust'-Khadynnyg I; 5 - Demir Sug II (from Mongush K. and Mongush M., 2019: 20, Fig. 2, 2);

6-9 - Arzhan II; 10-12 - Chinge Tei I (from: Chugunov, 2016: 337, 343, 345, 348, Fig. 165, 168, 169, 174). 
металлические и костяные украшения и к ней подвешивались необходимые предметы и оружие (Добжанский, 1990). Наиболее роскошный их ранний образец с обильным золотым декором видим у мужчины из основной могилы в кургане Аржан 2 (Чугунов, 2016: 337, рис. 165). Однако конструкция пояса, способ его застегивания, одевания периодически видоизменялся. Возможно, это было связано с изменением одежды, со своеобразной «модой», распространявшейся в ходе интенсивных контактов, характерных для кочевого мира. Н. Л. Членова считала наборные пояса одним из объединяющих компонентов скифского мира (Членова, 1993: 8).

В. Д. Кубарев и П. И. Шульга на основе материалов из пазырыкских курганов с берегов рек Чуи и Урсула делят кожаные наборные пояса на повседневные ремешковые (которые, скорее всего, носились под шубой и придерживали штаны) и боевые (которые отличались по технологическому исполнению), но в целом эта вариативность, выявляемая на основе разных креплений пряжек, блях, подвесок и оружия, не выпадает из рамок традиции; при этом она может быть специфичной для разных провинций одной скифо-сибирской общности (Кубарев, Шульга, 2007: 100-111). П. И. Шульга на материалах исследованных им комплексов в предгорьях Алтая реконструировал ремешковый тип пояса, распространённый у кочевников раннескифского времени Саяно-Алтая (Шульга, 2008: 104-118). Он состоял из 3-5 параллельных ремешков, скреплённых бронзовыми обоймами. Также в это время были и ремни из цельной кожаной полосы, вокруг которой одевались обоймы. Длина их достигала более полутора метров при ширине около 3 см. В основном подобные пояса относят к разряду парадных. Несколько экземпляров было найдены в Туве, и они детально проанализированы К. В. Чугуновым (Чугунов, 2016).

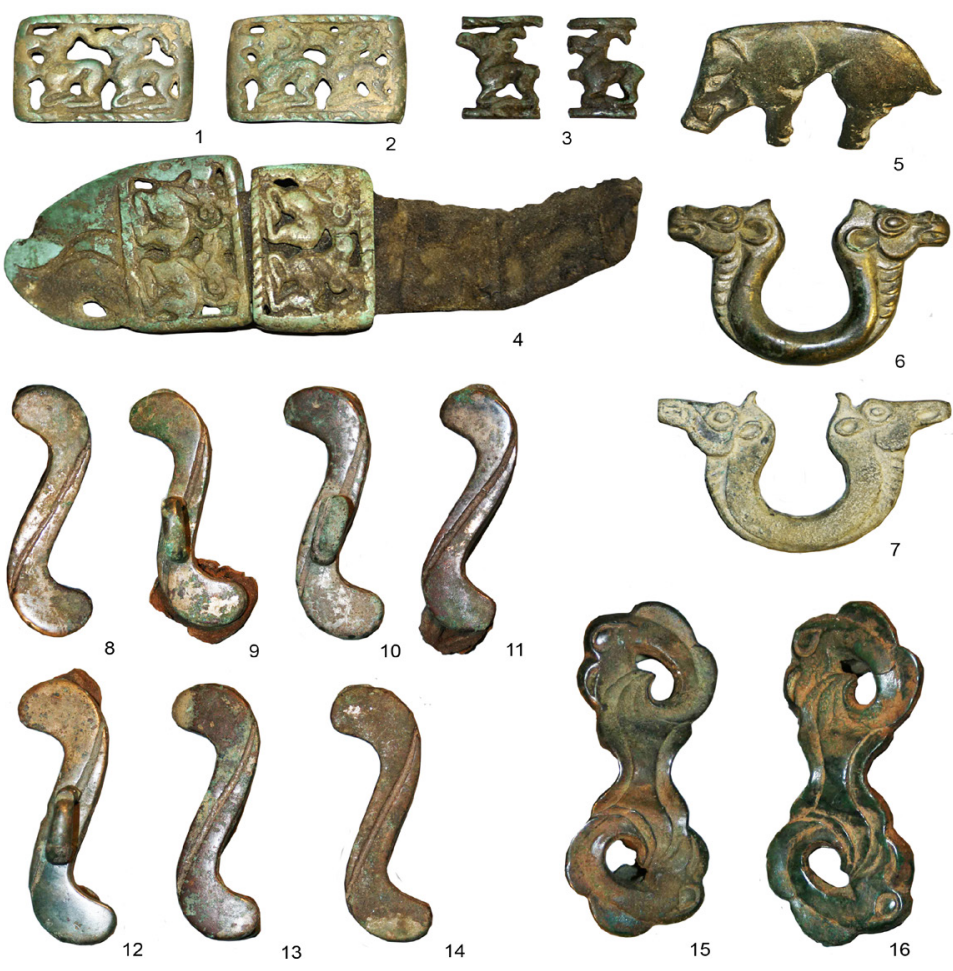

Рис. 6. Поясной набор из могильника Сыпучий Яр, бронза. Фото Вл. А. Семенова и М. Е. Килуновской, 20152.

Fig. 6. Belt decoration set from the Sypuchy Yar burial ground. Bronze. Photo by VI. A. Semenov and M. E. Kilunovskaya, 2015.
Всего для раннескифского времени - алды-бельской культуры ${ }^{1}$, несмотря на разрушение и ограбление могил, уже известно 10 более-менее целых наборных поясов с обоймами: 4 - в кургане Аржаан 2, 3 - в кургане Чинге-Тей 1 , и по одному в могильниках Демир-Суг II, Сыпучий Яр и УстьХадынныг 1 (там же: 336), а также есть довольно много случаев нахождения отдельных обойм в разграбленных могилах (рис. 5). Во всех случаях сохраняется один конец ремня, на который вплотную надеты несколько бронзовых обойм и наконечник. Обоймы украшены с обеих сторон фигурами животных, а наконечник фигурой в виде клюва хищной птицы.

Очень интересные поясные наборы обнаружены в могильнике Сыпучий Яр на правом берегу Енисея около пос. Баян-Кол (Семенов, 2001: 167-172). В кургане 4, который по погребальному обряду и инвентарю относится $\mathrm{K}$ поздней алды-бельской культуре, в могиле 1 был фрагмент пояса с четырьмя обоймами, украшенными изображениями горных козлов и фигурным наконечником (рис. 6), очень

\footnotetext{
${ }^{1}$ Алда-бельская культуры была выделена А. Д. Грачом и датируется VIII-VI вв. до н. э. (Грач, 1980). Для нее характерны курганы-кладбища, когда под одной насыпью, окруженной кольцом-крепидой, находятся несколько могил. Погребения совершаются в ямах с деревянными рамами или невысокими срубами, в каменных ящиках и деревянных колодах. Зачастую курганы примыкают вплотную друг к другу, образуя целые комплексы, вытянутые в широтном направлении. К алды-бельской культуре относится и царский курган Аржан-2.
} 
близкими по декору, обнаруженным в Усть-Хадынныге. В этой же могиле были две S-видных бляхи с головами грифонов на концах и двумя грибовидными заклепками на обратной стороне. Кроме того, в могиле 2 было захоронение подростка, за спиной которого лежали остатки портупеи, а именно семь S-видных блях, которые крепились с помощью двух кнопок-шпеньков, на трех из них на лицевой

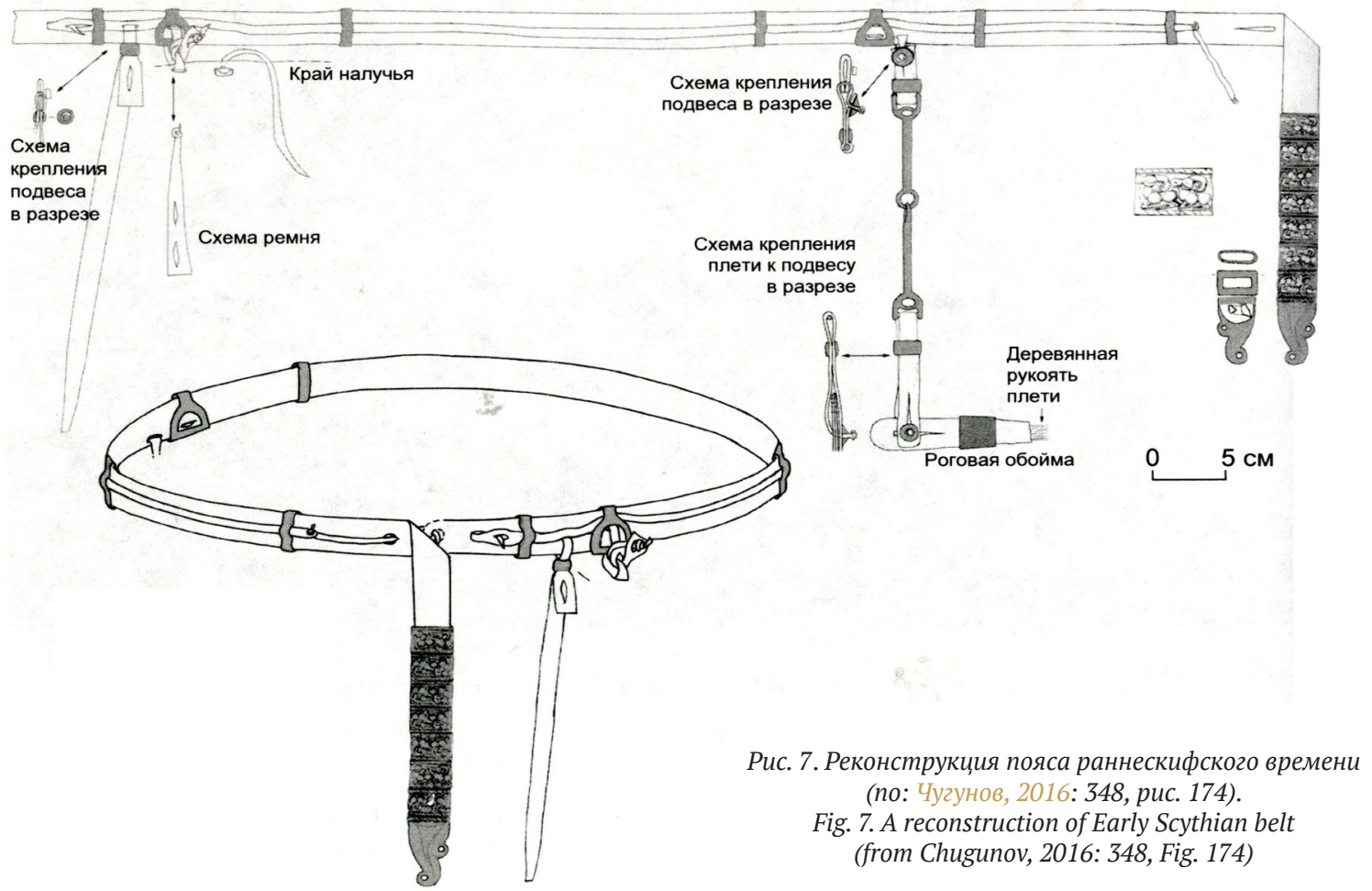

стороне были вертикальные петли для подвешивания; две подковообразные пряжки с протомами из голов верблюдов и шпеньками для крепления. Одна бляха в виде кабана имела горизонтальную петлю на обороте и, вероятно, к ней прикреплялся вертикальный ремень, который, в свою очередь, заканчивался стержневидной застежкой-костыльком. Все вещи сделаны очень качественно, с большим мастерством. Подобные поясные комплексы известны не только в Туве, но и на Алтае и Южном Урале (могильник Кичигино 1, см.: Таиров, 2015).

В 2012 г. могиле 5 Чинге-Тея 1 был найден прекрасно сохранившийся кожаный пояс с различными предметами фурнитуры, который позволил достоверно реконструировать устройство и способ ношения этих (видимо - парадных) костюмных аксессуаров, украшенных обоймами (Чугунов, 2016: 344-350) (рис. 7). Ремень был изготовлен из полосы кожи, сложенной вдвое, при этом он не был прошит и фиксировался только обоймами, часть которых имела петли на лицевой стороне, через которые был продет дополнительный узкий ремешок. Один из концов пояса был украшен обоймами с парными изображениями баранов и фигурным наконечником с двумя отверстиями, который не служил для застегивания ремня. Именно этот отрезок пояса с наконечником свисал вниз, а для завязывания использовался дополнительный узкий ремешок, который продевался через отдельное отверстие в широком ремне (там же: 174).

При такой реконструкции стало понятно, почему парадные пояса имели столь большую длину. У них также по бокам были подвешенные артефакты на тонких ремешках. Так, на чингетейском поясе висели стремечковидные удила, которые служили для подвешивания плети (которая хорошо сохранилась и в могиле, находившейся рядом). Эту реконструкцию стало возможным распространить и на парадные пояса из Аржана 2, где в основном погребении у мужчины было два пояса. Один парадный со свисающим концом, второй - очень длинный (190 см) (он либо обматывался вокруг тела несколько раз, либо носился через плечо). Это стрелковый пояс для ношения горита (рис. 8). Интересно, что под верхней одеждой были остатки третьего простого, повседневного пояса, скорей всего - веревочного, к которому крепился нож. Наборные пояса со свисающим концом, украшенные обоймами, были распространены до середины VI в. до н. э., то есть они исчезли одновременно с алдыбельской культурой. 


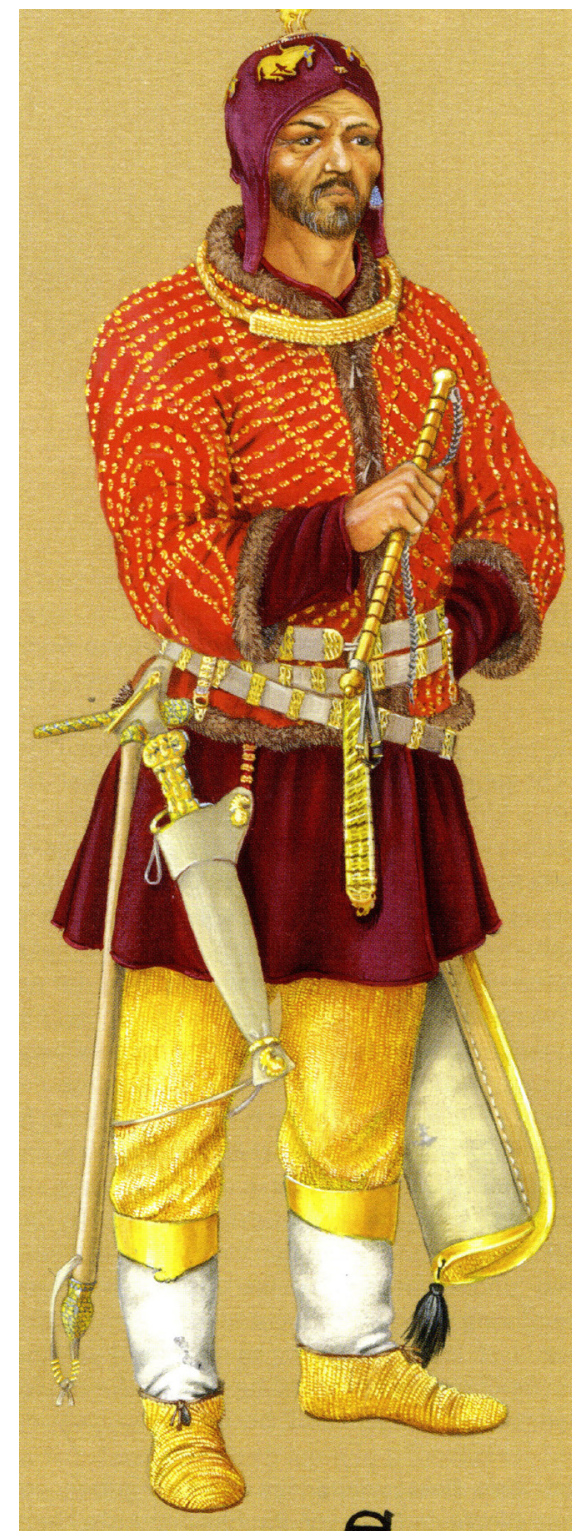

Рис. 8. Реконструкция костюма из кургана Аржан 2

(nо: Чугунов, 2016: 346, рис. 171).

Fig. 8. A reconstruction of apparel from Arzhan II kurgan

(from Chugunov, 2016: 346, Fig. 171)
В тувинской культуре также известны стрелковые пояса, представляющие собой ремни, которые одевались поверх матерчатых (см. у тувинцев Монголии: Amgalan, 2008: 104). Саaдак (чехол для лука) размещался слева, колчан со стрелами - справа, на отдельных ремнях. Саадак и колчан имели походный и боевой способы подвеса, менявшиеся с помощью металлических крючков и петель. В «походном» положении лук и стрелы размещались вертикально, в «боевом» положении колчан был наклонён вперёд. Ремень портупеи лучника был снабжён пряжкой, ускорявшей подготовку всадника к бою. Короткий рекурсивный сложный лук являлся отличительной чертой воиновкочевников на протяжении всего железного века. Это оружие при неоспоримой эффективности, однако, очень требовательно как к умениям владельца, так и к условиям окружающей среды, а также весьма сложно в изготовлении. При этом относительно небольшие размеры такого лука позволяют разместить его на поясе воина. Эти факторы привели к появлению такого изделия, как специальный чехол для переноски лука (саадак), возникший как развитие известного в археологии скифов горита (футляра для хранения лука и стрел вместе). Горит носился на поясе, будучи подвешен на специальном крюке, именуемом в археологии колчанным. Изображения на оленных камнях, которые отражают реалии скифского снаряжения, демонстрируют нам один пояс, на котором часто изображён и горит. При этом в погребениях скифского времени встречаются также небольшие колчаны, которые носились явно отдельно от лука. В гунно-сарматское время происходит эволюционный скачок лучного снаряжения, при сходных размерах, короткий, теперь уже сложносоставной, сигмавидный лук всадника становится массивнее. Размеры наконечников стрел кратно возрастают в тюркский, кыргызский и монгольский периоды, когда стрелковое вооружение конных лучников достигает апогея своего развития.

Во второй половине VI в. до н. э. в Саяно-Алтайском регионе формируются новые культурные традиции. Место археологических культур раннескифского времени занимают культуры скифо-сакского облика: в Горном Алтае формируется раннепазырыкская культура, сменившая бийкенскую (Тишкин, 2011: 271-290); в лесостепном Алтае в Барнаульском Приобье на смену большереченской приходит староалейская, а затем каменская (Фролов, 2008: 167-174, 181-182); в Туве алды-бельская культура сменяется уюкско-саглынской и т. д. Смена не была такой четкой и резкой; так, например, в ранних уюкско-саглынских памятниках прослеживаются алды-бельские традиции и, наоборот - в поздних алды-бельских захоронениях мы наблюдаем влияние пришельцев. Эталонным памятником раннего этапа уюкско-саглынской культуры является могильник Догээ-Баары 2, исследованный и опубликованный К. В. Чугуновым (Чугунов, 2007: 123-144).

В процессе наших раскопок по трассе проектируемой железной дороги Кызыл-Курагино в 2012-2016 гг. было исследовано более сотни погребальных памятников скифского времени («Дорога длиной ... , 2015: 123-190). Особенно интересны памятники в долине р. Ээрбек в Центральной Туве (Килуновская, 2015: 42-46). С Догээ-Баары здесь соотносятся могильник Саускен 7 и некоторые курганы на могильнике Саускен 3 (Семенов, Килуновская, 2014: 393-422). Это захоронения в 3-х-5-ти венцовых срубах, поставленных в глубокие ямы и перекрытых бревнами. Но под каменной насыпью есть еще сопроводительные детские погребения в ямах и колодах, а в могилах нет керамики. К позднему этапу алды-бельской культуры можно отнести погребальные комплексы могильников Эки-Оттуг 1 и 2 , 
которые представляют удлиненные каменные наброски, перекрывающие примыкающие друг к другу в широтном направлении отдельные коллективные захоронения (от двух до шести человек) в глубоких могильных ямах и сопровождающие их погребения (в основном детские) в небольших ямах, каменных ящиках и колодах. На дне глубоких ям прослеживаются деревянные рамы из уложенных по периметру в один-два бревен, дно выложено тонкими досками. В нескольких случаях прослежено перекрытие из тонких бревен или досок, положенных параллельно полу. В этих курганах Эки-Оттуга представлены и другие компоненты, которые можно считать пережитками алды-бельской культуры - «клады» конского снаряжения, «оленные камни», пекторали, серьги с конической подвеской и др.

B «переходных» памятниках с середины VI в. до н. э. появляется новый тип поясов, который отличается конструкцией и фурнитурой (он существует и в IV в. до н. э.). На смену цельным или раздвоенным поясам раннескифского времени (иногда они состоят из 3-5 параллельных ремешков), на которые надевались бронзовые обоймы, приходит пояс с использованием срединных ремешков, на который крепились украшения (Шульга, 2007: 27-40). Интересно, что в памятниках раннего этапа уюкскосаглынской культуры, как и в алды-бельской, мы не находим поясных пряжек (есть только подпружные).
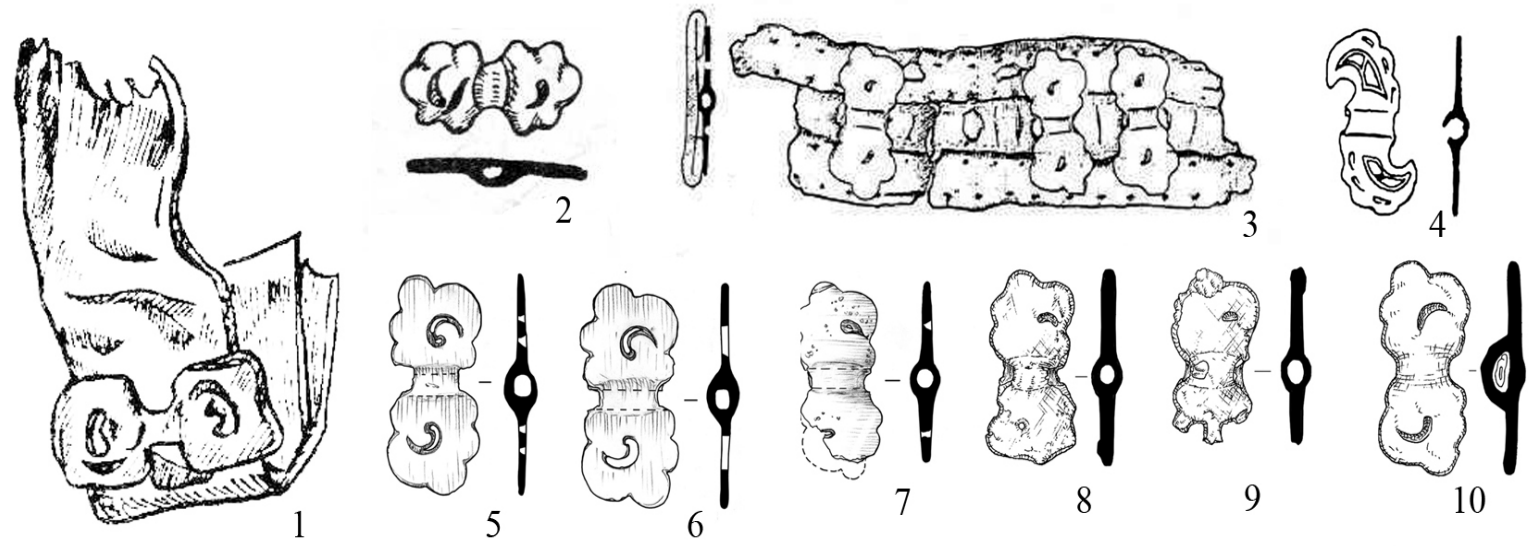

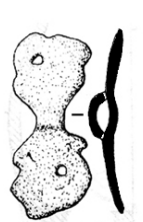

11

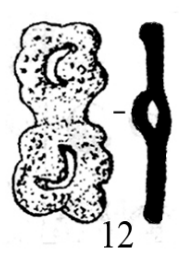

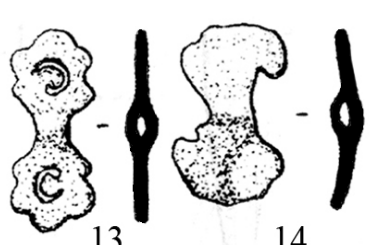

14

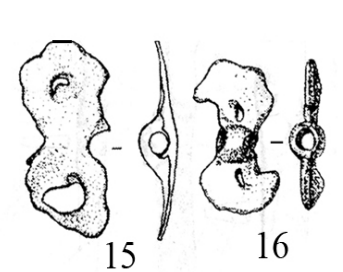

16

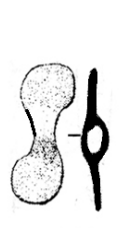

17

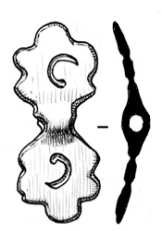

18

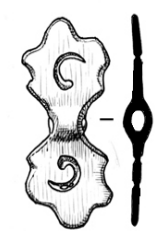

19

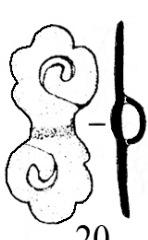

20

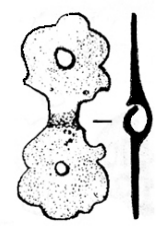

21

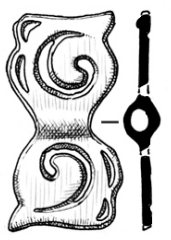

28

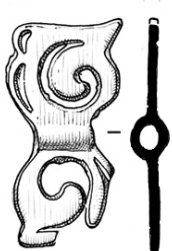

29

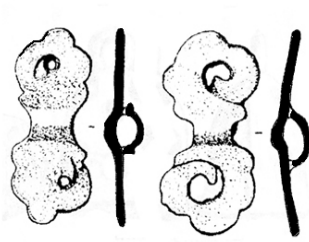

22

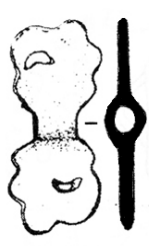

24

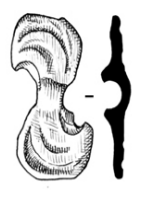

25

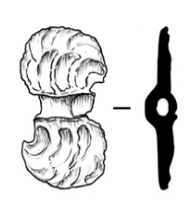

26

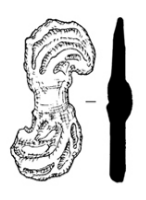

27

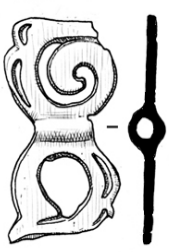

30

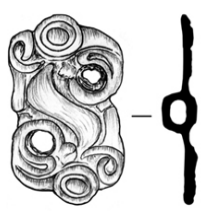

31
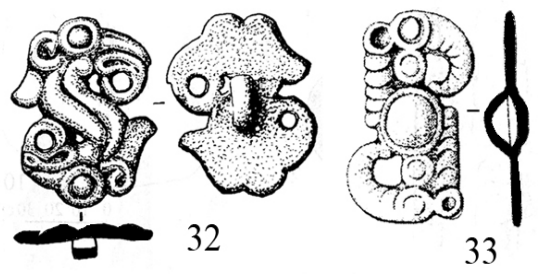

33

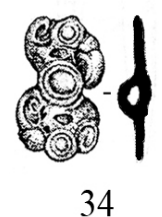

34

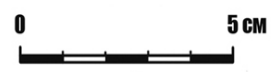

Рис. 9. Бабочковидные бляшки из курганов уюкско-саглынской культуры (бронза) и остатки поясов (1 - могильник Холаш, 3 - могильник Догэ-Баары). Рисунки М. Е. Килуновской, 2017 г.

Fig. 9. Batterfly-shaped plates from the kurgans of Oyuk-Saglyn culture (bronze) and remains of belts (1 - Kholash burial ground, 3 - Doge-Baary burial ground). Drawings by M. E. Kilunovskaya, 2017. 
К сожалению, мы не располагаем ни одной более-менее целой находкой пояса: практически 90\% всех погребений этого времени носят следы ограблений. Можно предположить, что в это время закрепления пояса осуществлялось с помощью завязывания срединного ремешка. Среди находок из могильников в долине р. Ээрбек встречаются бронзовые фигурные накладки с полусферами и обоймы с фрагментами тонких кожаных ремешков до 2 см в диаметре, которые скорее всего относились к украшениям ремешкового пояса, который мог идти под шубой и удерживать штаны. Пятикольчатые пряжки с фрагментами кожаных ремешков из могильника Саускен 3 могли выступать в роли распределителей. Фигурная обойма, достигающая в ширину до 5 см из кургана 1, могильника Эки-Оттуг 1 крепилась на основу кожаного пояса. Основной особенностью кожаных поясов в VI-III вв. до н. э. здесь являются полосы кожи, сложенные в два слоя прошитые сухожильными нитями либо широкие полосы толстой однослойной кожи. Процедура «простёгивания» изделий придаёт им эластичность и в целом укрепляет всю конструкцию. В ряде случаев сырьё для создания пояса поддаётся микроскопическому исследованию. Преобладают кожи крупного рогатого скота и лошадей.

Самыми распространенными из украшений таких поясов были «бабочковидные» бляшки-обоймы, различающиеся в незначительных деталях и по втулкам для продергивания ремешков (последние свидетельствуют, что они отливались в разных формах) (рис. 9). Ареал их распространения широк: от Верхнего Приобъя до Ордоса (Семенов, 1997: 19-20, рис. 23-26). При раскопках могильника Холаш в Монгун-Тайге такая бляшка была найдена in-situ притороченной к кожаному поясу. Керамические сосуды саглынской культуры, поставленные в погребение в каменном ящике, позволяют датировать его

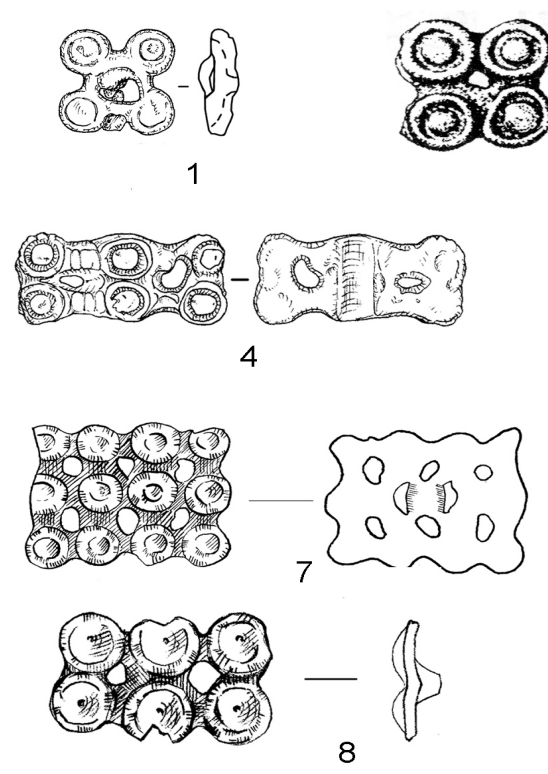

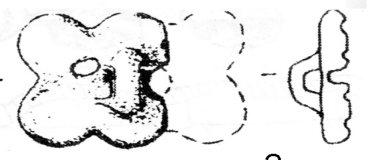

2

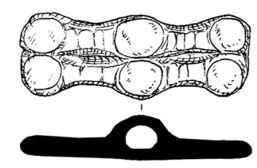

5

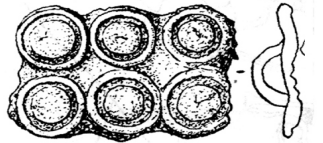

3
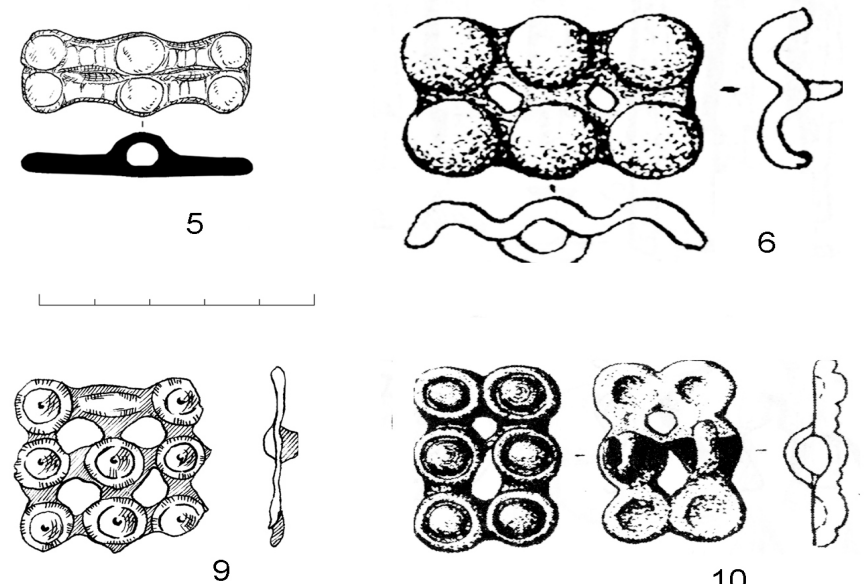

10

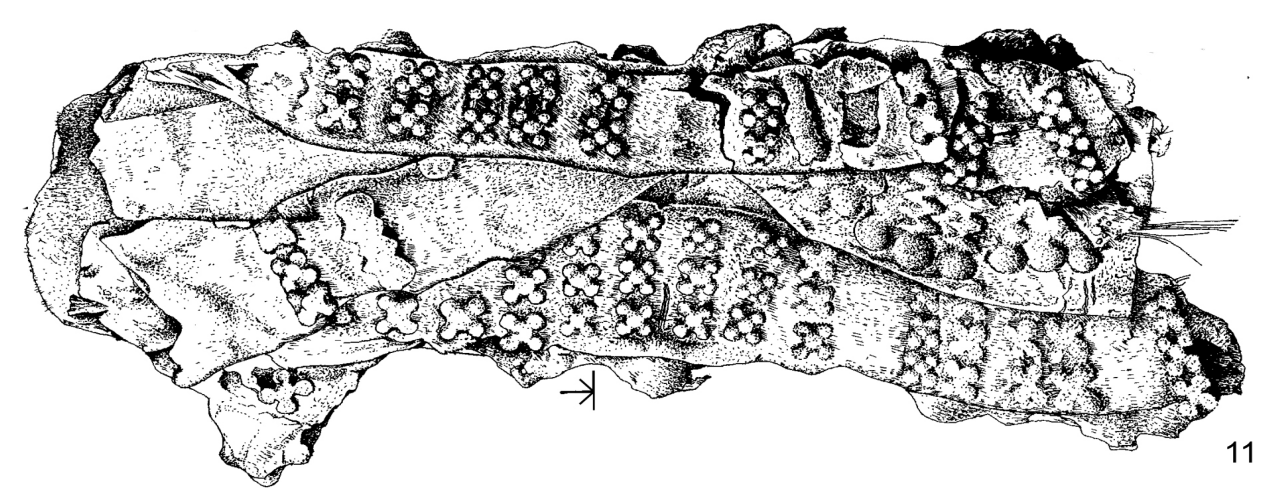

Рис. 10. 1-10 - поясные бляшки с полусферами (бронза) из Тувы и пояс из Забайкалья (11 - по: Харинский, 2004: 149, рис. 6, элемент 19).

Fig. 10. 1-10 - belt plates with hemispheres (bronze) from Tuva and a belt from Trans-Baikalia (11 - from Kharinsky, 2004: 149, Fig. 6, element 19). 
не ранее IV в.до н. э.Подобные бляшки-обоймы были обнаружены и на кожаном поясе, прикрепленными при помощи дополнительного ремешка, из кургана 17 могильника Догээ-Баары 2 (V-IV вв. до н. э.) (Чугунов, 2007: 131, ил. 13, элемент 1). В Ордосе этот тип поясных украшений появляется в период «Весен и Осеней» (771-476 гг. до н. э.) и существует в период «Сражающихся царств» (476-221 гг. до н. э.). В могильниках Маоцингоу и Таохунгбал в Ордосе бабочковидные бляшки встречаются in situ на поясах, где их количество достигает нескольких десятков.

Бляхи отличаются по декору. Можно их разделить на три основные группы: в виде стилизованных головок грифона, клюв которых выделен каплевидной прорезью, в виде стилизованных головок грифона с реберчатым орнаментом по поверхности; в виде стилизованных головок грифона с хохолком. Они были, по-видимому, престижными вещами (или апотропеями). Большое число бабочковидных блях (в том числе плакированных золотом) обнаружено в курганах уюкской культуры 1 и 2 на могильнике Кош-Пей I, датируемых рубежом VI и V вв. до н. э. (Семенов, 2010а). В этом случае можно сделать предположение, что Кош-пейские курганы в Уюкской котловине оставлены племенной знатью одновременной культуры, тогда как в долине реки Ээрбек по другую сторону Уюкского хребта обитали рядовые члены социума, сохранявшего во многом традиции своих предшественников / предков, носителей алды-бельской культуры.

На могильнике Эки-Оттуг 1 была обнаружена целая серия бронзовых поясных блях со щитком прямоугольной формы из совмещённых попарно или по три дисковидных выпуклостей - от четырёх до шести, которые до этого были неизвестны в Туве ${ }^{1}$, но широко распространены в Барнаульском Приобъе и Забайкалье, где они встречаются с бабочковидными украшениями (рис. 10). Нами была прослежена очень близкая связь между этими регионами в VI-V вв. до н. э. в погребальном инвентаре, а именно поясной фурнитуры и других предметов; при этом наблюдаются существенные различия в погребальном обряде. Иными словами, контакты между Тувой и степным Алтаем в 1 тысячелетии до н. э. осуществлялись на уровне обмена или диффузии престижных вещей, источником которых являлся, видимо, Китай (Килуновская, Фролов, 2020: 126-138).

На ремешок пояса надевались также бляхи с изображением животных, которые усиливали апотропеическую функцию пред-
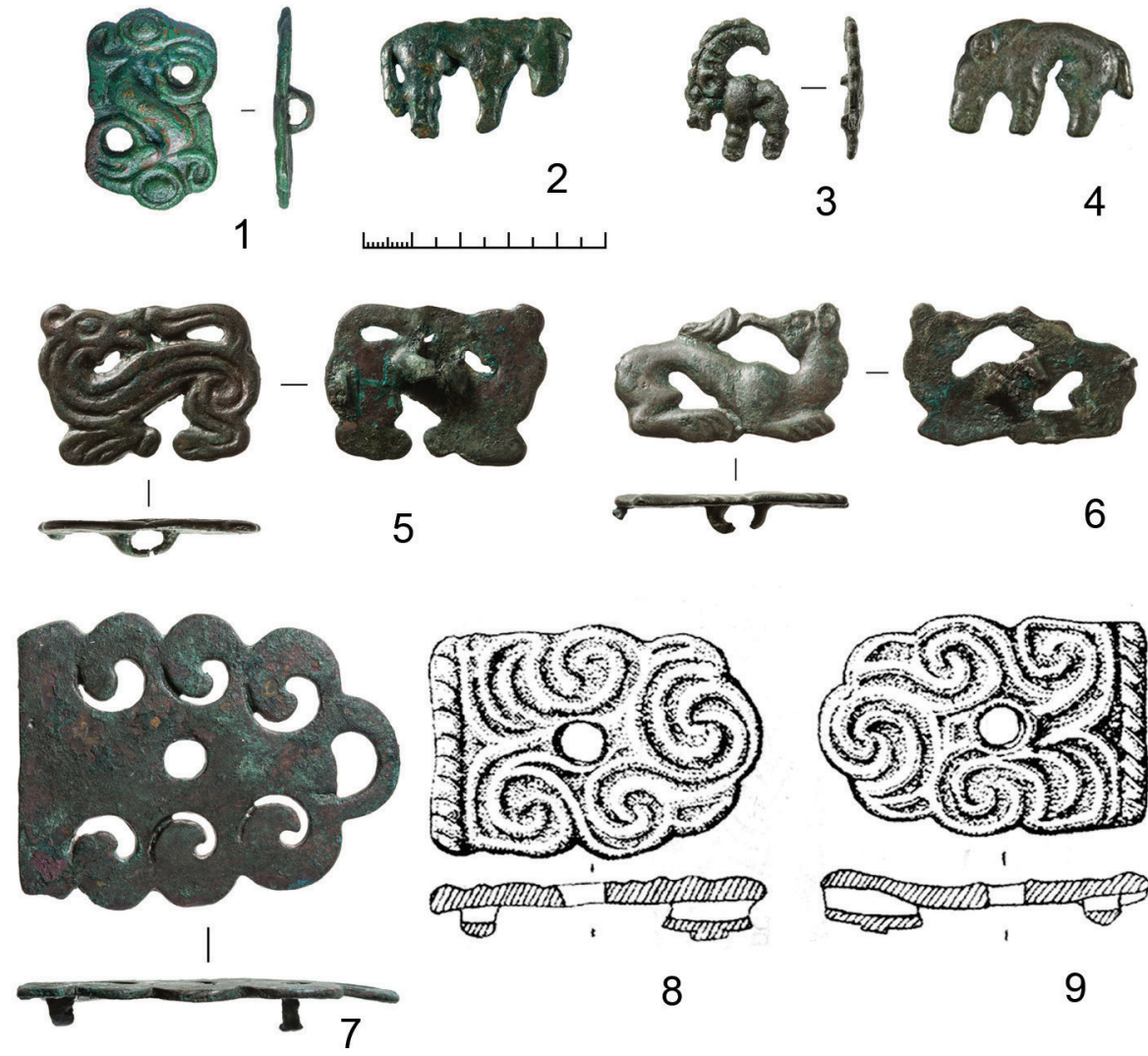

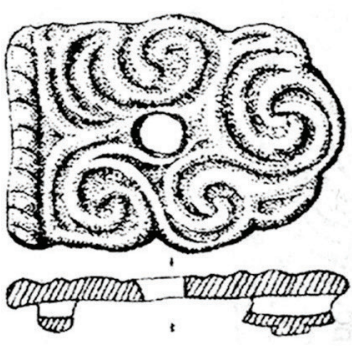

8

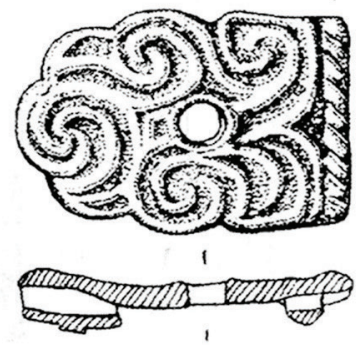

9

Рис. 11. Украшения пояса уюкско-саглынской культуры. Бронза. 1-7 - Тува; 8, 9 - Барнаульское Приобъе (по: Фролов, 2008: 364, рис. 133, элементы 1, 2). Fig. 11. Belt decorations of the Oyuk-Saglyn culture. Bronze, 1-7 - Tuva, 8-9 - Barnaul Ob' basin (from: Frolov, 2008: 364, Fig. 133, elements 1 and 2).

\footnotetext{
${ }^{1}$ В могильнике Аймырлыг (Д-7, гр. Х, объект 23) сохранились фрагменты плетёных текстильных поясов с перекинутыми через них кожаными ремешками (на которых могли подвесить ножны с ножом, сумочку с гребешком и зеркало). В одном случае сохранился фрагмент такого композитного пояса с кожаным ремешком и бронзовой бляшкой с шестью полусферами (Д-7). Материалы этого комплекса не опубликованы.
} 
мета. На могильнике Саускен 3 вместе с частью кожаного ремешка, на который были нанизаны шесть овальных обойм, являясь деталями колчанной портупеи (4 бронзовые и 3 железные) была обнаружена фигурка кабана (рис. 11, элемент 4). Эта фигурка находит близкие аналогии в материалах могильника Обские плёсы (Троицкая, Бородовский, 1994: 89, рис. 19, 5). Это пряжка в виде профильного изображения кабана с низко опущенной головой, так что «пятачок» на рыльце и копыта расположены в одну линию. Для этой фигуры характерно отсутствие излишней детализации. Она отличается особой лаконичностью. С обратной стороны пряжки припаяна вертикальная петля для крепления её к ремню. Она аналогична бляшке из алды-бельского комплекса Сыпучий Яр. В подобном стиле сделаны бляшки в виде фигурок коня из сруба 4 на могильнике Саускен 3 и козла из кургана 6 на могильнике Эки-Оттуг 2 (рис. 11, элементы 2, 3).

С Барнаульским Приобьем Туву объединяют поясные бляшки с изображением кошачьего хищника с головой, развёрнутой на спину (рис. 11 , элементы 5, 6). В кургане 3 на Эки-Оттуге 2 , который датируется второй половиной VI в. до н. э., были найдены два таких предмета. У них показаны лапы с когтями и задранный на спину хвост. У одного морда в виде клюва хищной птицы, у второго раскрытая пасть и на теле S-овидный завиток. Манера передачи второго зверя аналогична экземпляру из Фирсово, а также бляхам из Ордоса. Животные представлены припавшими на передние лапы. Бляхи с кошачьими хищниками с повернутыми на спину головами есть в материалах Дырестуйского могильника эпохи хунну, но там они переданы идущими (Давыдова, Миняев, 1988: 231, рис. 2, элементы 5, 6).

Еще одна деталь пояса находит соответствия в обоих сравниваемых нами регионах - это наконечник ремня в виде стилизованных головок грифонов или даже их клювов. В Туве он обнаружен в кургане 2 на могильнике Саускен 7 (рис. 11, элемент 7), а в Приобье - в могиле 184 на могильнике Фирсово XIV (рис. 11, элементы 8, 9). На оборотной стороне они имеют петлю для крепления к ремешку и шпенек для застегивания пояса.

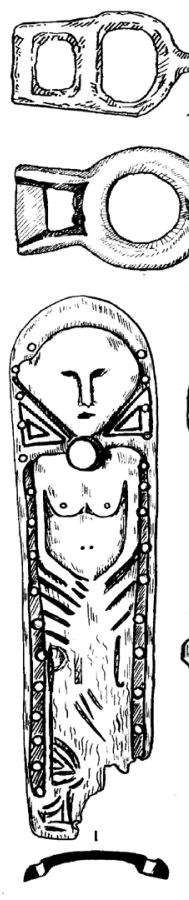

12
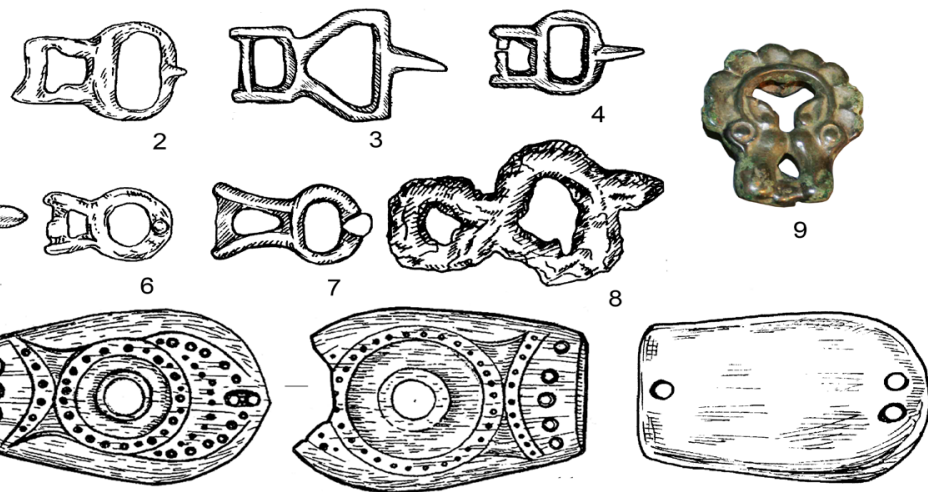

13
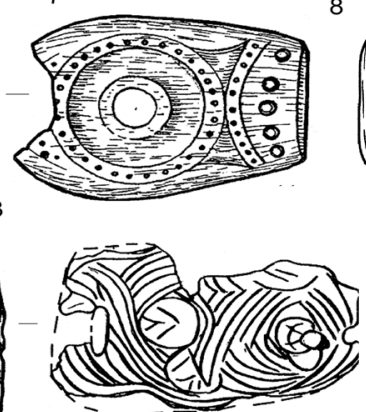

15

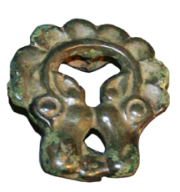

9
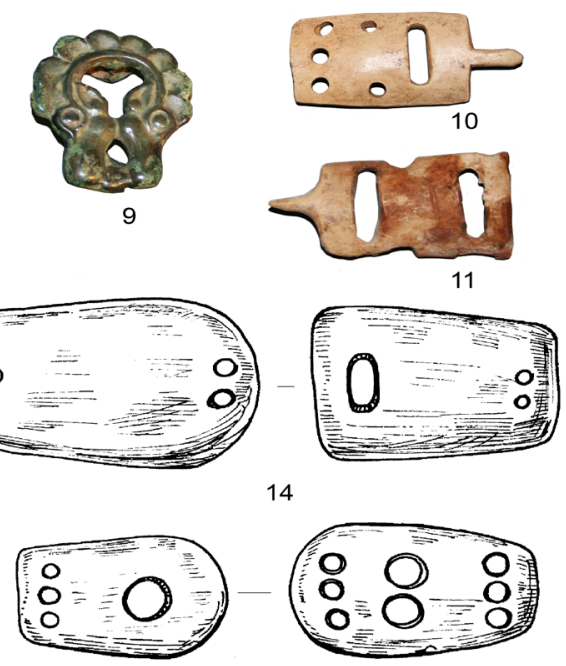

16
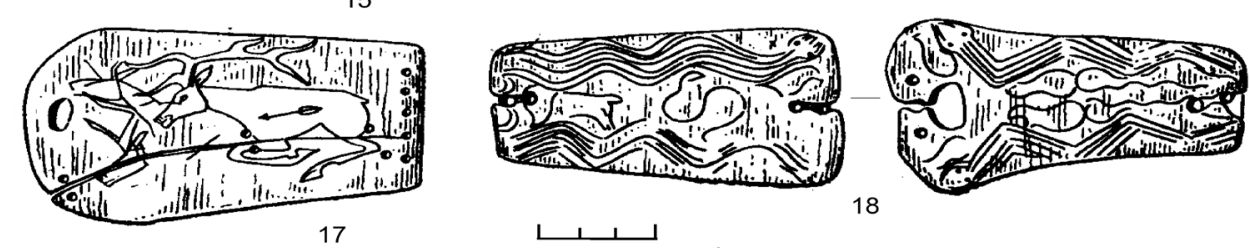

18

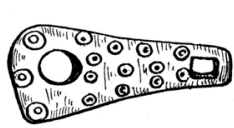

19

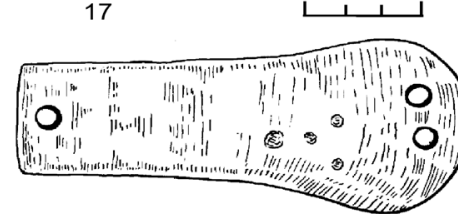

20

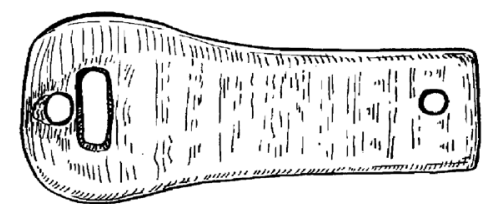

Рис. 12. Пряжки из комплексов озен-ала-белигского этапа уюкско-саглынской культуры:

1-7, 9 - бронза; 8 - железо; остальное - кость. Рисунки и фото М. Е. Килуновской, 2003 и 20142.

Fig. 12. Buckles from the of Ozen-Ala-Belig stage of Oyuk-Saglyn culture:1-7,9-bronze, 8-iron, other decorations made of bone.

Drawings and photo by M. E. Kilunovskaya, 2003 and 2014. 
Поясные пряжки появляются в скифских курганах Тувы на позднем этапе - озен-алабелигском (конец IV-II вв. до н. э.). Ключевым памятником являются могильники Суглуг-Хем и Хайыракан (Семенов, 2003), а также курганы на могильном поле Аймырлыг, Саускен 1, 2, 3, Красная Горка 2 и др. Для этого этапа характерно помещение в погребальные камерысрубы богато декорированных керамических сосудов. В могилах находится большое количество костей животных. Предметы вооружения (кинжалы, чеканы, ножи) в основном сделаны из железа. Столь значительные перемены, произошедшие под влиянием культур Алтая, нашли своё отражение и в поясной фурнитуре, и в конструкции пояса. Как раз в это время появляются пряжки, сделанные из железа, бронзы и кости (рис. 12). Металлические пряжки и отчасти костяные - с неподвижным язычком, имеют прямоугольную петлю для крепления на них кожаного ремня шириной 2-3 см. Широкое распространение получают большие костяные пряжки-пластины прямоугольной и трапециевидной формы со скругленным широким концом. Они имеют с одной стороны несколько отверстий для крепления к ремню, а с другой - одно или два отверстия для завязывания. Они зачастую богато декорировались циркульным и геометрическим орнаментом, резными изображениями животных и т. д. Свое развитие такие пряжки-пластины получают в эпоху хунну (II-I вв. до н. э.), когда появляются бронзовые ажурные пряжки-пластины (Килуновская, Леус, 2020: 97-126).

Чрезвычайно интересна поясная гарнитура позднескифского времени, включающая, кроме пряжек, различного рода бронзовые, золотые и костяные бляшки, пятикольчатые бляшки для продергивания тонких кожаных ремешков, железные пряжки-обоймы, колокольчики, костылевидные иложечковидные подвески из бронзы и кости (рис. 13), многие из которых находят аналогии как в культуре сюнну, так и в погребальных комплексах усуней Семиречья (Семенов, 2010b).

Нам удалось воссоздать удалось одежду воина позднескифского времени благодаря находке неграбленого погребения на могильнике Суглуг-Хем. Умерший был одет в короткую куртку, украшенную по бортам вырезанными из золотого листа скребущими пантерами. Швы на куртке и штанах были закрыты золотыми полосками. Голову опоясывала матерчатая диадема, украшенная золотыми фи- 

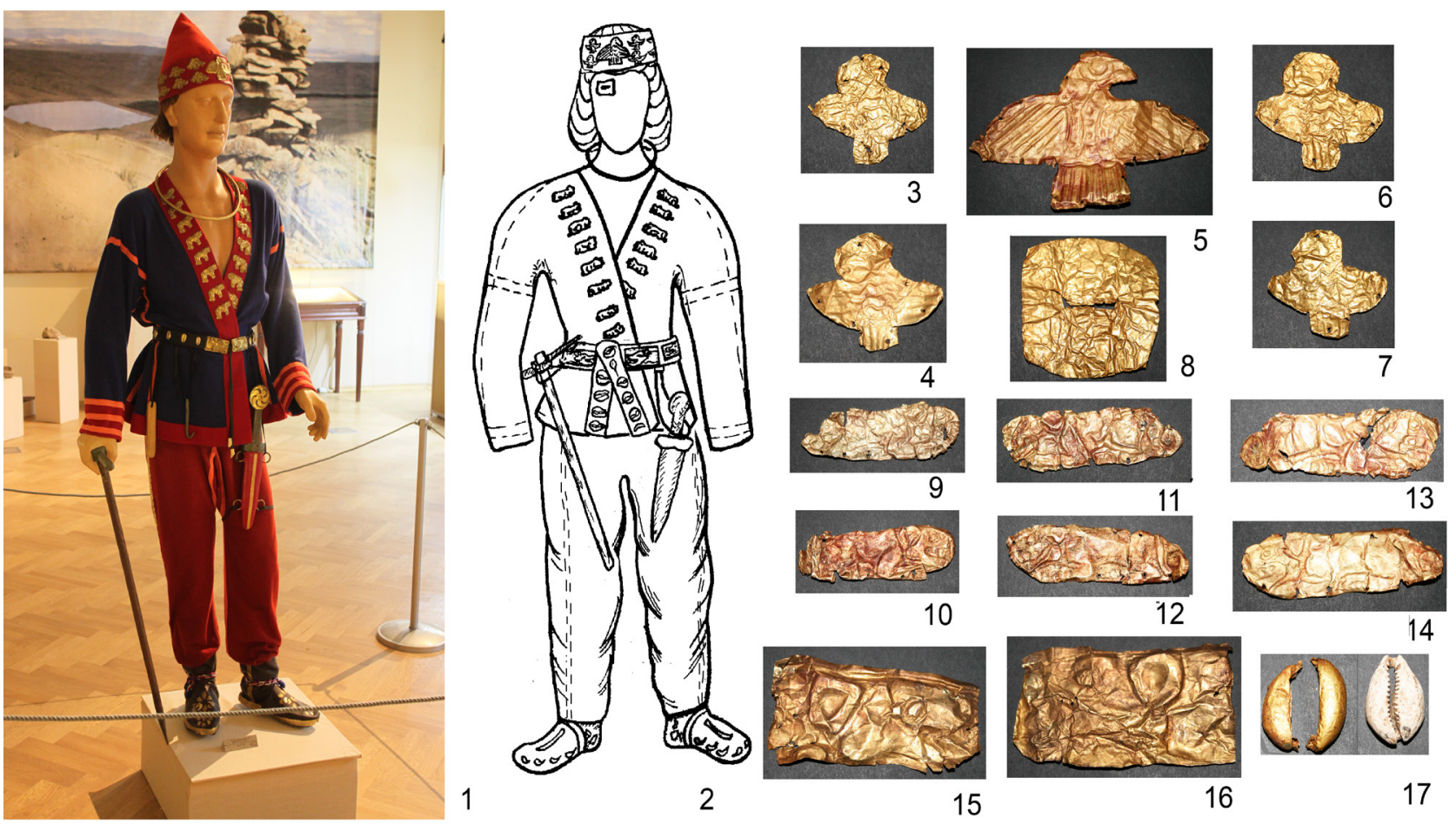

10
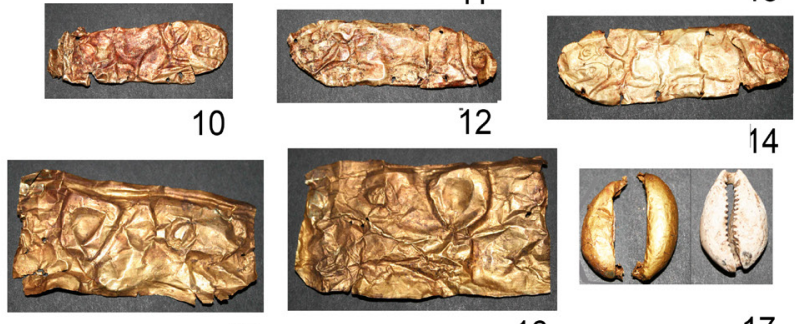

15
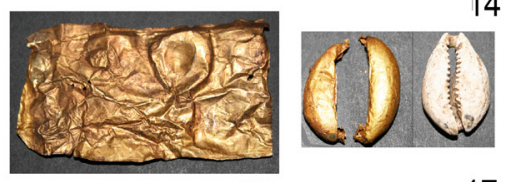

16

17

Рис. 14. Реконструкция костюма воина позднескифского времени: 3-16 - украшения одежды и пояса из могильника Суглуг-Хем 1 объект 26, золото. Рисунки и фото Вл. А. Семенова и М. Е. Килуновской 2003, 2005, 2016 г2.

Fig. 14. A reconstruction of an apparel of a Late Scythian warrior: 3-16 - clothes and belt decorations, from Object 26 on the Suglug Khem I burial ground. Gold. Drawings and photos by Vl. A. Semenov and M. E. Kilunovskaya, 2003, 2005 and 2016.

гурками орлов: 22 из них были нашиты в два ряда, а в центре располагалась «кокарда» размером 90×50 мм. На шее была железная гривна, плакированная золотой фольгой. Обувь также была обшита геометрическими фигурами из золота и золотыми лентами. Куртка была подпоясана кожаным поясом, на котором не было пряжки, он просто завязывался. По периметру пояса и на свисающих концах нашиты раковины каури, обёрнутые золотой фольгой, по центру друг напротив друга нашиты две золотые пластины с изображением голов льва. На поясе на тонких ремешках висели чекан и акинак из железа (рис. 14).

Конструкция пояса у хунну, по-видимому, такая же, как у озен-ала-белигцев. Но нужно отметить, что пряжки-пластины в это время находятся только в женских погребениях, в то время как мужской пояс крепился только с помощью железных, бронзовых и костяных рамчатых (круглых или прямоугольных) пряжек, часть которых имела неподвижный язычок. В этих погребениях уже изредка появляются пряжки с подвижным язычком. Такие мужские пряжки существуют и у тюрков, а затем у всех народов Саяно-Алтая. Материалы могильника Ала-Тей 1 в Центральной Туве дают нам представление о том, каков был состав поясного набора, но были ли это исключительно кожаные пояса или наоборот, в основе преобладал текстиль, пока сложно сказать. Женские пояса преимущественно создавали из бронзовых изделий. Медные сплавы благоприятно влияют на сохранность органических материалов, поэтому в процессе раскопок были зафиксированы следы основы. Скорее всего, в составной модели женского пояса перемычками между элементами (рамчатые бляшки, кольца и т. д.) выступали кожаные тонкие ремешки «протянутые» по широкой основе. Но возможно, есть варианты, где пояс имеет плотную широкую текстильную основу, а на него нашиваются с помощью тоненьких кожаных шнурков бронзовые имитации раковин каури.

Различие в оформлении поясных пряжек для мужчин и женщин наблюдается и в тувинской культуре. Как мы уже указывали, к поясу крепились различные предметы с помощью различных ремешков из кожи и ткани. Они пропускались через специальные пряжки дерги (правильнее - бляшки-обоймы), которые закреплялись на основном поясе. Такая же конструкция была и в скифское время, а наибольшее развитие получила у тюрков. Дерги делались из бронзы и серебра, причем у мужчин они обязательно гладкие, без орнамента, а женские, наоборот, обязательно орнаментировались, причем иногда весьма тщательно и сложно (особенно это относится к пряжкам, украшающим свадебный костюм) (Потапов, 
1969: 217). С. И. Вайнштейн приводит одну интересную серебряную пряжку-терги с изображение козерога из Национального музея Республики Тыва, которая по стилю изображения аналогична поясной бляхе, от которой идёт вниз ремешок для подвешивания, из второго Пазырыкского кургана (Вайнштейн, 1974: 100; рис. 65, элементы 1, 6) (рис. 15). Это ещё раз подтверждает определенную преемственность, которая существуют между скифской и тувинской культурами.

В поясной фурнитуре в первом тысячелетии до н. э. можно проследить устойчивые тенденции к изменению, связанные с появлением новых аксессуаров в костюме, предметами, которые носились на поясе, модой, и возможно статусом, который приобретал этот компонент одежды в ту или иную эпоху. Здесь мы имеем в виду то, что в скифское время большое внимание уделялось боевым поясам (по большей частью мужским), а на позднем этапе скифской культур и особенно у хунну они особенно тщательно украшались для женского костюма и приобрели скорей декоративное значение, как символ богатой женщины ${ }^{1}$.

\section{Заключение}

Пояс, как и любая вещь, использовался в контексте культуры не только в утилитарных целях. Обычная одежда кочевника была лишена карманов, и все необходимое носилось на поясе. Помимо практического, важным назначением пояса = перепоясывания/ опоясывания были апотропеические свойства и функция защиты, оберега, сохранения; он также всегда служил показателем общественного ранга. Для этого использовали различные украшения в виде бляшек, пряжек, подвесок и т. д., которые в скифосибирском мире украшались изображениями животных или их репрезентативных частей - клювов или головок орлов или грифонов, головок оленей и верблюдов, копыт и т. д. В кочевых сообществах скифского времени портупейный пояс, безусловно, был воинским атрибутом. Ярким воплощением важного символического значения пояса является его изображения на оленных камнях - монументах предскифского и раннескифского времени, распространенных по всей степной полосе Евразии. В основе оленного камня, возможно, лежит идея божественного «Первопредка» - героизированного воина, носителя «непреходящей славы». Трехчленное деление оленного камня отражает представление о космосе: верхний мир маркируется тремя косыми линиями и кругами-серьгами и отделяется от среднего «ожерельем» или гривной/пекторалью; в среднем мире обитают копытные олени, козлы, архары, а также хищники, стилизованные изображения которых представлены в средней зоне камня; она подчеркивается линией-поясом, к которому пририсовывается оружие, уводящее нас в нижний мир.

Все эти представления возникли к началу 1 тысячелетия до н. э., когда охотники-скотоводы перешли к кочевому хозяйствованию, и существуют до сих пор в традиционной тувинской культуре. Такие элементы, как шерстяные и веровочные пояса, стрелковые или портупейные ремни с некоторым количеством подвесных ремешков, на которых подвешивается все самое необходимое - все это имеет свои корни в культуре «скифских» племен, формирование которой происходило на Саяно-Алтае. Нужно отметить также и присущую для номадов разницу в мужском и женском - это цвета текстильного пояса (тувинский кур), материал - плетеная веревка из тонких полос кожи или конопли или же поясок

${ }^{1}$ По мнению С. С. Миняева (1948-2020), которое высказывал неоднократно в своих докладах на конференциях последних лет, но не успел опубликовать, речь идет о наложнице. 
из козьей шерсти, оформление пряжек и ременных украшений, состав располагаемого на поясе инвентаря (ножи и точильный камень, колчан со стрелами, а иногда и горит с луком у мужчин; ножичек, сумочка с игольником, шилом и зеркалом у женщин). Естественно, все это менялось с развитием и сменой археологических культур, но культурная преемственность в горных районах - относительных природных изолятах - всегда присутствует, что связано и с сохранением определенного хозяйственно-культурного типа и природных условий.

\section{Благодарности}

Авторы статьи выражают признательность за разрешение воспользоваться материалами А. И. Евсееву, Н. В. Полосьмак, К. В. Чугунову, Я. В. Фролову и А. В. Харинскому.

\section{СПИСОК ЛИТЕРАТУРЫ}

Артамонов, М. И. (1973) Сокровища саков. М. : Искусство. 280 с.

Вайнштейн, С. И. (1974) История народного искусства Тувы. М. : Наука. 224 с.

Вайнштейн, С. И. (1991) Мир кочевников центра Азии. М. : Наука. 296 с.

Грач, А. Д. (1980) Древние кочевники в центре Азии. М. : ГРВЛ. 256 с.

Давыдова, А. В., Миняев, С. С. (1988) Пояс с бронзовыми бляшками из Дырестуйского могильника // Советская археология. № 4. С. 230-233.

Даржа, В. К. (2009) Традиционные мужские занятия тувинцев. Т. 1. Хозяйство. Охота. Рыбалка. Кызыл : Тувинское книжное издательство. 592 с. $164 \mathrm{c}$

Дьяконова, В. П. (1975) Погребальный обряд тувинцев как историко-этнографический источник. Л. : Наука.

Добжанский, В. Н. (1990) Наборные пояса кочевников Азии. Новосибирск : НГУ. 164 с.

«Дорога длиной в тысячелетия...» (2015) / отв. ред Н. Ф. Соловьева. СПб. : Любавич, 196 с.

Килуновская, М. Е. (2015) Памятники декоративно-прикладного искусства из могильников скифского времени в долине р. Ээрбек (Тыва) // Ранний железный век Евразии от архаики до рубежа эр. Центр, периферия и модели культурных взаимодействий / отв. ред. Д. Г. Савинов. СПб. : Скифия-принт. 138 с. С. 42-46.

Килуновская, М. Е., Леус, П. М. (2020) Ажурны бронзовые пряжки эпохи хунну в Туве // Научное обозрение Саяно-Алтая. № 1 (25). С. 97-125.

Килуновская, М. Е., Фролов, Я. В. (2020) Сравнительный анализ поясных украшений скифского времени Барнаульского Приобья и Тувы // Вещь в контексте погребального обряда / отв. ред. С. А. Яценко. М. : РГГУ. 270 с. C. $126-138$.

Кочевники Евразии на пути к империи. Из собрания Государственного Эрмитажа. Каталог выставки (2012) / науч. ред. М. Б. Пиотровский. СПб. : Гос.Эрммитаж ; АО «Славия». 271 с.

Кубарев, В. Д., Шульга, П. И. (2007) Пазырыкская культура (курганы Чуи и Урсула). Барнаул : Изд-во Алтайского гос. университет. 282 с.

Мир кочевников из археологических коллекций Государственного Эрмитажа. Каталог выставки (2013) / науч. ред. М. Б. Пиотровский. СПб. : Гос. Эрмитаж ; АО «Славия». 132 с.

Монгуш, К. М., Монгуш, М. А. (2019) Погребения раннескифского времени с предметами парадной поясной фурнитуры могильника Демир-Суг II в Туве // Учёные записки музея-заповедника «Томская Писаница». Вып. 9. Кемерово: КРИПКиПРО. 128 с. С. 17-29.

Полосьмак, Н. В., Баркова, Л. Л. (2005) Костюм и текстиль пазырыкцев Алтая (IV-III вв. до н. э.). Новосибирск : ИНФОЛИО. 232 с.

Потапов, А. П. (1969) Очерки народного быта тувинцев. М. : Наука. 402 с.

Прокофьева, Е. Д. (1971) Шаманские костюмы народов Сибири // Сборник МАЭ. Т. XXVII. С. 23-67.

Семенов, Вл. А. (1997) Монгун-Тайга (археологические исследования в Туве в 1994-1995 гг.). СПб. : ИИМК РАН. 48 с., 52 рис.

Семенов, Вл. А. (2001) Сыпучий Яр - могильник алды-бельской культуры в Туве // Евразия сквозь века / отв. ред. И. Я. Фроянов, С. Н. Астахов. СПб. : Фил. фак. СПбГУ. 250 с. С. 167-172.

Семенов, Вл. А. (2003) Суглуг-Хем и Хайыракан. Могильники скифского времени в Центрально-тувинской котловине. СПб. : Петербургское востоковедение. 240 с.

Семенов, Вл. А. (2010a) Кош-Пейские курганы в тувинской долине царей (VI-V вв. до н. э.) // Древние культуры Евразии. Материалы конференции посвященной 100-летию А. Н. Бернштама / ред. В. А. Алёкшин. СПб. : Инфо-ол. 326 c. C. $241-246$. 
Семенов, Вл. А. (2010b) Усуни на севере Центральной Азии // Археология, этнография и антропология Евразии. № 3 (43). С. 101-112.

Семенов, Вл. А. (2019) Фрагменты ближневосточного гобелена из Пятого Пазырыкского кургана // Научные труды. Выпуск 49. С. 3-13.

Семенов, Вл. А., Килуновская, М. Е. (2014) Могильник скифского времени Саускен 3 в долине реки Ээрбек (Республика Тыва) // Археология древних обществ Евразии / отв. ред. В. А. Алёкшин. СПб. : Арт-Экспресс. 464 с. C. 393-422.

Таиров, А. Д. (2015) Комплекс раннесакского времени кургана 5 могильника Кичигино I в Южном Зауралье // Сакская культура Сарыарки в контексте изучения этносоциокультурных процессов Степной Евразии / отв. ред. А. 3. Бейсенов. Алматы : НИЦИА «Бегазы-Тасмола». 218 с. С. 300-319.

Тишкин, А. А. (2011) Бийкенская культура Алтая аржано-майэмирского времени: содержание и опыт периодизации // «Terra Scythica». Материалы международного симпозиума (17-23 августа 2011 г., Денисова пещера, Горный Алтай) / отв. ред. В. И. Молодин, С. Хансен. Новосибирск : Изд-во ИАЭТ СО РАН. 408 с. С. $273-290$.

Троицкая, Т. Н., Бородовский, А. П. (1994) Большереченская культура лесостепного Приобья. Новосибирск : Наука. 184 с.

Тува в беге времени. Каталог выставки (2014) / рук. И. Б. Шалугина. М. : Музей декоративно-прикладного искусства. 96 с.

Фролов, Я. В. (2008) Погребальный обряд населения Барнаульского Приобья в VI в. до н. э. - II в. н. э. (по данным грунтовых могильников). Барнаул : Азбука. 480 с.

Харинский, А. В. (2004) Погребальный ритуал населения Северного Прибайкалья в середине I тыс. до н. э. начале I тыс. н. э. (по материалам могильника Байкальское XXXI // Центральная Азия и Прибайкалье в древности. Вып. 2. Улан-Удэ : Изд-во Бурятского госуниверситета. 207 с. С. 134-150.

Черемисин, Д. В. (2008) Искусство звериного стиля в погребальных комплексах рядового населения пазырыкской культуры: семантика звериных образов в контексте погребального обряда. Новосибирск : Изд-во ИАЭТ СОРАН. 136 с.

Членова, Н. Л. (1993) О степени сходства компонентов материальной культуры в пределах «Скифского мира» // Петербургский археологический вестник. № 7. С. 49-77.

Чугунов, К. В. (2007) Могильник Догээ-Баары 2 как памятник начала уюкско-саглынской культуры Тувы (по материалам раскопок 1990-1998 гг.) // А. В. Сборник научных трудов в честь 60-летия А. В. Виноградова / науч. ред. С. В. Хаврин. СПб. : Культ-Информ-Пресс. 190 с. С. 123-144.

Чугунов, К. В. (2016) Парадные пояса кочевников Азии в раннескифское время // Алтай в кругу Евразийских древностей / отв. ред. А. П. Деревянко, В. И. Молодин. Новосибирск : Изд-во ИАЭТ СОРАН. 624 с. С. 336-356.

Шульга, П. И. (2007) О конструкции раннескифских поясов с Алтая и прилегающих территорий // Алтае-Саянская горная страна и соседние территории в древности. Новосибирск : Изд-во ИАЭТ СОРАН. 288 с. С. 27-40.

Шульга, П. И. (2008) Снаряжение верховой лошади и воинские пояса на Алтае : в 2 ч. Барнаул : Азбука. Ч. I. Раннескифское время. 276 с.

Яценко, С. А. (2006) Костюм древней Евразии (ираноязычные народы). М. : Восточная литература. 664 с.

Amgalan, M. (2008) The ciltural monuments of Western Mongolia. Ulanbaatar : Monsudar. 212 p.

Escitas. Tesoros de Tuvб. Catбlogo (2008) / Dir. Gen. J. A. Cortйs Garrido. Valencia: Fundaciyn MARQ. 171 p.

Im zeichen des goldenen Greifen. Konigsgraber der Scythien (2007) / Dir. W. Menghin. Munich : Prestel. 339 S.

Дата поступления: 12.12.2020 г.

\section{REFERENCES}

Artamonov, M. I. (1973) Sokrovishcha sakov [The Treasures of the Saks]. Moscow, Iskusstvo. 280 p. (In Russ.).

Vainshtein, S. I. (1974) Istoriia narodnogo iskusstva Tuvy [A history of folk art in Tuva]. Moscow, Nauka. 223 p. (In Russ.).

Vainshtein, S. I. (1991) Mir kochevnikov tsentra Azii [The world of nomads of the center of Asia]. Moscow, Nauka. 296 p. (In Russ.).

Grach, A. D. (1980) Drevnie kochevniki v tsentre Azii [Ancient nomads in Central Asia]. Moscow, Nauka. 256 p. (In Russ.).

Davydova, A. V. and Miniaev, S. S. (1988) Poias s bronzovymi bliashkami iz Dyrestuiskogo mogil'nika [A belt with bronze plates from the Dyrestuy burial ground]. Sovetskaia arkheologiia, no. 4, pp. 230-233. (In Russ.).

Darzha, V. K. (2009) Traditsionnye muzhskie zaniatiia tuvintsev [Traditional Tuvan male pursuits]. Kyzyl, Tuvan publishing house. 592 p. (In Russ.)

D'iakonova, V. P. (1975) Pogrebal'nyi obriad tuvintsev kak istoriko-etnograficheskii istochnik [The funeral rite of the Tuvans as a historical and ethnographic source]. Leningrad, Nauka. 164 p. (In Russ.) 
Dobzhanskii, V. N. (1990) Nabornye poiasa kochevnikov Azii [Decorated belts of nomads of Asia]. Novosibirsk, NGU. 164 p. (In Russ.).

«Doroga dlinoi v tysiacheletiia...» [“The millennia-long road...”] (2015) / ed. by N. F. Solovyev. St. Petersburg, Liubavich, 196 p. (In Russ.).

Kilunovskaya, M. E. (2015) Pamiatniki dekorativno-prikladnogo iskusstva iz mogil'nikov skifskogo vremeni v doline r. Eerbek (Tyva) [Monuments of decorative and applied art from the burial grounds of the Scythian time in the valley of the Eerbek River (Tuva)]. In: Rannii zheleznyi vek Evrazii ot arkhaiki do rubezha er. Tsentr, periferiia i modeli kul'turnykh vzaimodeistvii [Early Iron Age of Eurasia from the Archaic to the turn of the Era. Center, periphery and model of cultural interactions] / ed. by D. G. Savinov. St. Petersburg, Skifiia-print. 138 p. Pp. 42-46. (In Russ.).

Kilunovskaya, M. E. and Leus, P. M. (2020) Azhurny bronzovye priazhki epokhi khunnu v Tuve [Bronze openwork buckles of the Xiongnu period in Tuva]. Nauchnoe obozrenie Saiano-Altaia, no. 1 (25), pp. 97-125. (In Russ.).

Kilunovskaya, M. E. and Frolov, Ya. V. (2020) Sravnitel'nyi analiz poiasnykh ukrashenii skifskogo vremeni Barnaul'skogo Priob'ia i Tuvy [Comparative analysis of Scythian belt jewelry of the Barnaul Ob region and Tuva]. In: Veshch' $v$ kontekste pogrebal'nogo obriada [A thing in the context of a funeral rite] / ed. by S. A. Yatsenko. Moscow, RGGU. 270 p. Pp. 126-138. (In Russ.).

Kochevniki Evrazii na puti k imperii. Iz sobraniia Gosudarstvennogo Ermitazha. Katalog vystavki [The nomads of Eurasia on their way to the Empire from the collection of the State Hermitage Museum: An exhibition catalogue] (2012) / ed. by M. B. Piotrovskii. St. Petersburg, Gos.Ermmitazh; AO «Slaviia». 271 p. (In Russ.).

Kubarev, V. D. and Shul'ga, P. I. (2007) Pazyrykskaia kul'tura (kurgany Chui i Ursula) [Pazyryk culture (Chui and Ursula mounds)]. Barnaul, Izd-vo Altaiskogo gos.universitet. 282 p. (In Russ.).

Mir kochevnikov iz arkheologicheskikh kollektsii Gosudarstvennogo Ermitazha. Katalog vystavki [The world of nomads from the archaeological collections of the State Hermitage Museum: An exhibition catalogue] (2013) / ed. by M. B. Piotrovskii. St. Petersburg, Gos.Ermmitazh; AO «Slaviia». 132 p. (In Russ.).

Mongush, K. M. and Mongush, M. A. (2019) Pogrebeniia ranneskifskogo vremeni s predmetami paradnoi poiasnoi furnitury mogil'nika Demir-Sug II v Tuve [Burials of the Early Scythian time with items of ceremonial belt fittings of the Demir-Sug II burial ground in Tuva]. In: Uchenye zapiski muzeia-zapovednika «Tomskaia Pisanitsa». Vol. 9. Kemerovo, KRIPKiPRO. 128 p. Pp. 17-29. (In Russ.).

Polos'mak, N. V. and Barkova, L. L. (2005) Kostium i tekstil' pazyryktsev Altaia (IV-III vv. do n. e.) [Costume and textiles of the Pazyryk people of Altai (IV-III centuries BC)]. Novosibirsk, INFOLIO. 232 p. (In Russ.).

Potapov, L. P. (1969) Ocherki narodnogo byta tuvintsev [The Tuvans: sketches of the folk lifestyle and related household activities]. Moscow, Nauka, GRVL. 402 p. (In Russ.).

Prokof'eva, E. D. (1971) Shamanskie kostiumy narodov Sibiri [Shaman costumes of the peoples of Siberia]. Sbornik MAE. Vol. XXVII. Pp. 23-67. (In Russ.).

Semenov, Vl. A. (1997) Mongun-Taiga (arkheologicheskie issledovaniia v Tuve v 1994-1995 gg.) [Mongun-Taiga: archaeological research in Tuva in 1994-1995]. St. Petersburg, IIMK RAN. 48 p., 52 ill. (In Russ.).

Semenov, Vl. A. (2001) Sypuchii Iar - mogil'nik aldy-bel'skoi kul'tury v Tuve [Sypuchy Yar, the burial ground of the Aldy-Belsky culture in Tuva]. In: Evraziia skvoz' veka [Eurasia through the ages] / ed. by I. Ya. Froianov and S. N. Astakhov. St. Petersburg, Fil. fak. SPbGU. 250 p. Pp. 167-172. (In Russ.).

Semenov, Vl. A. (2003) Suglug-Khem i Khaiyrakan. Mogil'niki skifskogo vremeni v Tsentral'no-tuvinskoi kotlovine [SuglugKhem and Khayyrakan. Burial grounds of the Scythian period in the Central Tuva basin]. St. Petersburg, Peterburgskoe vostokovedenie. 240 p. (In Russ.).

Semenov, Vl. A. (2010a) Kosh-Peiskie kurgany v tuvinskoi doline tsarei (VI-V vv. do n. e.) [Kosh-Pei mounds in the Tuva valley of the Kings (VI-V centuries BC)]. In: Drevnie kul'tury Evrazii [Ancient Cultures of Eurasia]. Proceedings of the conference dedicated to the 100th anniversary of A. N. Bernshtam / ed. by V. A. Alekshin. St. Petersburg, Info-ol. 326 p. Pp. 241-246. (In Russ.).

Semenov, Vl. A. (2010b) Usuni na severe Tsentral'noi Azii [The wusun in northeastern central Asia]. Archaeology, Ethnology and Anthropology of Eurasia, no. 3 (43), pp. 101-112. (In Russ.).

Semenov, Vl. A. (2019) Fragmenty blizhnevostochnogo gobelena iz Piatogo Pazyrykskogo kurgana [Fragments of an Middle Eastern tapestry from kurgan Pazyryk V]. Nauchnye Trudy, vol. 49, pp. 3-13. (In Russ.).

Semenov, Vl. A. and Kilunovskaya, M. E. (2014) Mogil'nik skifskogo vremeni Sausken 3 v doline reki Eerbek (Respublika Tyva) [The Sausken III Scythian burial ground in the valley of the Eerbek River, Republic of Tuva]. In: Arkheologiia drevnikh obshchestv Evrazii [Archeology of ancient societies of Eurasia] / ed. by V. A. Alekshin. St. Petersburg, Art-Ekspress. 464 p. Pp. 393-422. (In Russ.).

Tairov, A. D. (2015) Kompleks rannesakskogo vremeni kurgana 5 mogil'nika Kichigino I v Iuzhnom Zaural'e [The complex of the Early Saka time of kurgan 5 of the Kichigino I burial ground in the Southern Trans-Urals]. In: Sakskaia kul'tura Saryarki v kontekste izucheniia etnosotsiokul'turnykh protsessov Stepnoi Evrazii [Saka culture of Saryarka in the context 
of the study of ethno-socio-cultural processes of Steppe Eurasia] / ed. by A. Z. Beisenov. Almaty, NITsIA «Begazy-Tasmola». 218 p. Pp. 300-319. (In Russ.).

Tishkin, A. A. (2011) Biikenskaia kul'tura Altaia arzhano-maiemirskogo vremeni: soderzhanie i opyt periodizatsii [Biyken culture of the Arzhano-Mayemir in Altai: content and experience of periodization]. In: "Terra Scythica». Proceedings of the International Symposium (August 17-23, 2011, Denisova Cave, Gorny Altai) / ed. by V. I. Molodin and S. Khansen. Novosibirsk, Izd-vo IAET SO RAN. 408 p. Pp. 273-290. (In Russ.).

Troitskaia, T. N. and Borodovskii, A. P. (1994) Bol'sherechenskaia kul'tura lesostepnogo Priob'ia [Bolsherechenskaya culture of the forest-steppe Ob' region]. Novosibirsk, Nauka. 184 p. (In Russ.).

Tuva v bege vremeni. Katalog vystavki [Tuva through time: an exhibition catalogue] (2014) / hand. I. B. Shalugina. Moscow, Muzei dekorativno-prikladnogo iskusstva. 96 p. (In Russ.).

Frolov, Ya. V. (2008) Pogrebal'nyi obriad naseleniia Barnaul'skogo Priob'ia v VI v. do n.e. - II v. n.e. (po dannym gruntovykh mogil'nikov) [The funeral rite of the population of the Barnaul Ob' region from $6^{\text {th }}$ century $B C$ to $2^{\text {nd }}$ century $A D$, from burial grounds data]. Barnaul, Azbuka. 480 p. (In Russ.).

Kharinskii, A. V. (2004) Pogrebal'nyi ritual naseleniia Severnogo Pribaikal'ia v seredine I tys. do n. e. - nachale I tys. n. e. (po materialam mogil'nika Baikal'skoe XXXI) [The funeral ritual of the population of the Northern Baikal region in the middle between $1^{\text {st }}$ millennium $\mathrm{BC}$ and $1^{\text {st }}$ millennium $\mathrm{AD}$ : from the data of the Baikal burial ground XXXI]. In: Tsentral'naia Aziia i Pribaikal'e v drevnosti [Central Asia and the Baikal Region in antiquity]. Issue 2. Ulan-Ude, Izd-vo Buriatskogo gosuniversiteta. 207 p. Pp. 134-150. (In Russ.).

Cheremisin, D. V. (2008) Iskusstvo zverinogo stilia v pogrebal'nykh kompleksakh riadovogo naseleniia pazyrykskoi kul'tury: semantika zverinykh obrazov v kontekste pogrebal'nogo obriada [The Art of the Animal Style in the burial complexes of the ordinary population of the Pazyryk culture: semantics of animal images in the context of the funeral rite]. Novosibirsk, Izd-vo IAET SORAN. 136 p. (In Russ.).

Chlenova, N. L. (1993) O stepeni skhodstva komponentov material'noi kul'tury v predelakh «Skifskogo mira» [On the degree of similarity of the components of material culture within the "Scythian World"]. Peterburgskii arkheologicheskii vestnik, no. 7, pp. 49-77. (In Russ.).

Chugunov, K.V.(2007) Mogil'nik Dogee-Baary 2 kak pamiatnik nachala uiuksko-saglynskoi kul'tury Tuvy (po materialam raskopok 1990-1998 gg.) [Mogilnik Dogee-Baary 2 as a monument of the beginning of the Uyuk-Saglynsk culture of Tuva: from the excavations in 1990-1998)]. In: A. V. Collection of research papers in honor of the 60th anniversary of A.V. Vinogradov / ed. by S. V. Khavrin. St. Petersburg, Kul't-Inform-Press. 190 p. Pp. 123-144. (In Russ.).

Chugunov, K.V. (2016) Paradnye poiasa kochevnikov Azii v ranneskifskoe vremia [Ceremonial belts of nomads of Asia in the Early Scythian time]. In: Altai v krugu Evraziiskikh drevnostei [Altai in the circle of Eurasian Antiquities] / ed. by A. P. Derevianko and V. I. Molodin. Novosibirsk, Izd-vo IAET SORAN. 624 p. Pp. 336-356. (In Russ.).

Shul'ga, P. I. (2007) O konstruktsii ranneskifskikh poiasov s Altaia i prilegaiushchikh territorii [On the construction of Early Scythian belts from the Altai and adjacent territories]. In: Altae-Saianskaia gornaia strana $i$ sosednie territorii $v$ drevnosti [Altai-Sayan mountain country and neighboring territories in ancient times]. Novosibirsk, Izd-vo IAET SORAN. 288 p. Pp. 27-40. (In Russ.).

Shul'ga, P. I. (2008) Snariazhenie verkhovoi loshadi i voinskie poiasa na Altae [Equipment of a riding horse and military belts in the Altai] : in 2 parts. Barnaul, Azbuka. Part I. Ranneskifskoe vremia [Early Scythian time]. 276 p. (In Russ.).

Yatsenko, S. A. (2006) Kostium drevnei Evrazii (iranoiazychnye narody) [Costume in ancient Eurasia: Iranian-speaking peoples]. Moscow, Vostochnaia literatura. 664 p. (In Russ.).

Amgalan, M. (2008) The ciltural monuments of Western Mongolia. Ulanbaatar, Monsudar. 212 p.

Escitas. Tesoros de Tuvb. Catblogo (2008) / Dir. Gen. J. A. Cortis Garrido. Valencia, Fundaciun MARQ. 171 p.

Im zeichen des goldenen Greifen. Konigsgraber der Scythien (2007) / Dir. W. Menghin. Munich, Prestel. 339 p.

Submission date: 12.12 .2020 . 